\title{
The Contours and Correlates of Child Poverty Across Immigrant Generations
}

\author{
Brian C. Thiede ${ }^{\mathrm{a}, 1}$, Matthew M. Brooks ${ }^{\mathrm{a}}$, and Leif Jensen ${ }^{\mathrm{a}}$
}

May 1, 2020

\begin{abstract}
Recent cohorts of U.S. children increasingly consist of immigrants or the immediate descendants of immigrants, a demographic shift that has been implicated in high rates of child poverty. Analyzing data from the 2014-2018 Current Population Survey (CPS) and using the U.S. Census Bureau's Supplementary Poverty Measure, we describe differences in child poverty rates across immigrant generations (first-, second-, and third+-generation immigrant children) and how these are rooted in generational differences in the prevalence and impact of key poverty risk factors. We find that (1) poverty rates among Hispanic children are very high, particularly among first- and second- generation with two foreign-born parents children; (2) limited parental employment is by far the greatest risk factor for child poverty compared to having a young or poorly educated parent, living in a single-headed family or disadvantaged place of residence; (3) inter-generational differences in risk factor prevalence explain non-trivial shares of corresponding child poverty gaps; and (4) the patterns observed among the Hispanic population are moderated by race and ethnicity. Understanding the intersection of poverty risks, immigrant generation, and race has significant policy implications has America's population continues to grow more diverse along multiple social axes.
\end{abstract}

Keywords: Immigration, Immigrant Generations, Child Poverty, Inequality, Family, Employment

\section{Acknowledgements}

Previous versions of this paper were presented at the University of Wisconsin-Madison's Institute for Research on Poverty and the 2018 annual meeting of the Population Association of America. Thiede gratefully acknowledges support from the extramural grants program of the Institute for Research on Poverty at the University of Wisconsin-Madison. The authors acknowledge assistance provided by the Population Research Institute at Penn State University, which is supported by an infrastructure grant from the Eunice Kennedy Shriver National Institute of Child Health and Human Development (P2CHD041025). Thiede and Jensen's work was also supported by the USDA National Institute of Food and Agriculture and Multistate Research Project \#PEN04623 (Accession \#1013257).

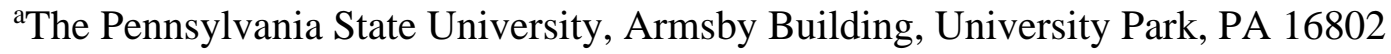

${ }^{1}$ Corresponding author: 111A Armsby Building; University Park, PA 16802;

Phone: 814-865-2561; Email: bct11@psu.edu 


\section{Introduction and background}

Racial and ethnic diversity is steadily increasing in the United States, driven in large part by the changing composition of cohorts at the bottom of the age distribution (Alba \& Foner 2015; Johnson \& Lichter 2008; Lichter 2013). As of 2018, more than half of school-aged children identified their race and ethnicity as something other than non-Hispanic white (Frey 2019; U.S. Census Bureau 2019). Hispanics alone make up 25.0 percent of these youngest age groups (Frey 2019). Importantly, these changes in ethno-racial composition have been driven by shifting patterns of immigration and fertility among immigrants (Johnson \& Lichter 2008). An implication is that recent cohorts of children are characterized by increasing diversity in both race and immigrant generation (i.e., one's status as an immigrant, immediate descendent of an immigrant, or otherwise), which each operate as important axes of socioeconomic inequality in the United States (Lichter 2013; Rumbaut \& Portes 2001; Thiede \& Brooks 2018). These changes raise the prospect that the youngest cohorts of U.S. children will be characterized by increasingly large and complex differentials in wellbeing and opportunity.

Racial and ethnic disparities in poverty and other socioeconomic outcomes among children have been well-documented (Drake \& Rank 2009; Eggebeen \& Lichter 1991; Lichter et al. 2015; Thiede et al. 2017; Timberlake 2007), but considerably less attention has been placed on variation in children's economic status across immigrant generations (see Lichter et al. 2005, Thiede \& Brooks 2018, Van Hook et al. 2004). The most recent evidence about inter-generational disparities in child poverty has simply described rather than explained these differentials (Thiede \& Brooks 2018). There is furthermore little research on how the advantages and disadvantages of membership in particular ethno-racial groups intersect with immigrant generation status to shape the economic circumstances of children. Understanding these patterns can provide insight into 
processes of economic integration across immigrant generations in at least two respects. First, the early-life circumstances of children shape the likelihood that they experience upward (or downward) mobility over their own life course (Duncan et al. 1998, 2010). Second, cross-sectional patterns of inter-generational differences in socioeconomic outcomes provide insight into the trajectory that new immigrants and their descendants are likely to experience as they constitute and form emergent first- and second-generation cohorts. (Alba \& Nee 1997, 2009).

With these motivations in mind, we study the patterns and explanations of child poverty differentials across immigrant generations. We focus our analysis primarily on the Hispanic population since they are the modal ethno-racial group of first- and second-generation children. ${ }^{1}$ Drawing on decomposition methods (e.g., Van Hook et al. 2004) and the related framework for comparative poverty research proposed by Brady and colleagues (2017), we begin by answering three empirical questions about the population of Hispanic children. First, how does the prevalence of poverty-generating characteristics vary across immigrant generations? Second, how does the magnitude of poverty risk associated with each characteristic vary across immigrant generations? Third, given these differences in the magnitude of poverty risk associated with key factors, what share of observed poverty rates, and differences therein, can be explained by the prevalence of risk factors? We then expand our focus beyond Hispanics and answer a fourth question: How does the prevalence and impact of poverty risk factors differ between Hispanics and other ethno-racial groups?

\footnotetext{
${ }^{1}$ Within our analytical sample, Hispanics make up 56.9 percent of first- and second-generation children. The corresponding figure for non-Hispanic whites is 16.4 percent, for blacks 9.2 percent, and for Asians 17.5 percent.
} 


\section{Immigration, racial diversity, and inequalities in child poverty}

Growing ethno-racial diversity among recent cohorts of children in the United States shapes and contextualizes policy debates about child poverty and the social safety net (Parolin \& Brady 2019; Shaefer et al. 2018; Smeeding 2016). These demographic changes-driven by immigration, marriage and fertility patterns, and other changes in U.S. society-are broadly correlated with large and growing shares of children born into disadvantaged circumstances (Lichter et al. 2015, Thiede et al. 2017). Over the 2008-2014 period, for example, 43.2 percent of non-Hispanic black infants were born into poor families, as were over a third of Hispanic infants (36.5\%), 17.7 percent of non-Hispanic whites, and 11.7 percent of Asian newborns (Thiede et al. 2017). In some respects, these differentials represent the most recent manifestation of longstanding ethno-racial inequalities in child poverty (Call \& Voss 2016; Eggebeen \& Lichter 1991, Lichter et al. 2005; Voss et al. 2006). However, new forms of diversity—particularly along the lines of nativity—are being driven by immigration and high fertility among first- and second-generation immigrants relative to other groups (Humes et al. 2011; Woods \& Hanson 2016). Nativity and immigrant generation may therefore be increasingly salient dimensions of inequality among children. As such, understanding contemporary child poverty dynamics and developing effective social policy will require new attention to how levels of poverty and its determinants vary across immigrant generations.

However, policymakers currently have limited evidence to work from. A robust social science literature has documented substantial variation in social, economic, and demographic outcomes across immigrant generations (National Academies of Sciences 2016; Park \& Myers 2010; Parrado \& Morgan 2008; Turner \& Thiede 2016), but few studies have analyzed such differences in poverty among children (for exceptions see Borjas 2011; Brooks \& Thiede 2018; Jensen \& Chitose 1994; Lichter et al. 2005). This knowledge gap is particularly important given 
the long-term costs of exposure to economic disadvantage during childhood. Early exposure to poverty has large and sometimes irreversible effects on developmental outcomes that shape attainment over the life course (Bradley \& Corwyn 2002; Duncan et al. 1998). ${ }^{2}$ Consequently, an unequal distribution of childhood exposure to poverty across immigrant generations may contribute to inter-generational disparities in education, health, and other commonly studied laterlife outcomes (Abraído-Lanza et al. 2016; Tran \& Valdez 2017; Turner \& Thiede 2016; Qian \& Qian 2019).

The previous studies that have tracked child poverty differentials across immigrant generations provide clear motivation for additional research (Lichter et al. 2005; Oropesa \& Landale 1997; Van Hook et al. 2004). For example, Lichter et al. (2005) find that in 2000, the child poverty rate among first-generation Mexican immigrants (36.1\%) was nearly 14 percentage points higher than among third+-generation Mexican-Americans (22.8\%). Likewise, the child poverty rate was 10 percentage points higher among first-generation non-Hispanic whites (19.3\%) than the comparable third+ generation (9.3 percent). Notably, Lichter and colleagues also show that the magnitude and direction of these inter-generational disparities vary by race and country of origin. For example, rates of poverty among non-Hispanic black children in the first immigrant generation $(26.2 \%)$ were lower than among the third generation (34.0\%). This finding demonstrates that first- and second-generation immigrants are not always disadvantaged vis-à-vis the third, and that the choice of reference group matters.

The magnitude of inter-generational disparities has also changed over time. Comparing all children of immigrants (regardless of country of birth) with children of native-born adults, Van Hook et al. (2004) show persistent—and in some cases growing — disparities in child poverty from

\footnotetext{
${ }^{2}$ With reference to the counterfactual of being non-poor in the United States.
} 
1969 through 1999. Overall, they find that the gap in child poverty between children of immigrants and natives increased from -2.5 percentage points (11.6\% vs. $14.1 \%)$ in 1969 to 6.9 percentage points $(21.6 \%$ vs. $14.7 \%) .{ }^{3}$ They further show that the rapid increase in poverty among children of immigrants over this time period can be explained in part by compositional changes—namely shifts in race and ethnicity, parental employment, marital status, and time in the United States. Importantly, Van Hook et al. (2004) also note that the growing divergence in the economic circumstances of immigrants' children and those of natives can be explained by disproportionate increases in education and work hours among native-born parents.

Large inter-generational disparities in child poverty have also been observed in more recent data. Thiede and Brooks (2018) find that, overall, first-generation non-citizen children and secondgeneration children with two foreign-born parents experienced much higher rates of poverty in 2015-6 (30.2\% and 25.7\%, respectively) than second-generation children with one foreign-born parent and third+-generation children (approximately 17\% each). These recent data also suggest that race and ethnicity modify patterns of inter-generation stratification. The ranges in poverty rates across generations vary from 26.0-42.0 percent among Hispanic children to 10.4-23.8 percent among Asian children. Beyond these studies, there is surprisingly little analysis of differences in child poverty across immigrant generations (see also Borjas 2011). This evidence gap, in the context of projected future growth in the demographic diversity of youth cohorts, motivates new research on this topic.

\footnotetext{
${ }^{3}$ There is evidence of variation by racial and ethnic group. Among Mexican's for example, disadvantage among children of immigrants increased from 1.5 percentage points in 1969 to 7.9 percentage points in 1999; but among Asians the advantage among immigrants remained fairly stable at 0.8 percentage points in 1969 and 0.3 percentage points in 1999 .
} 


\section{Conceptual framework}

We draw on the logic of demographic standardization and decomposition to conceptualize and analyze inter-generational and disparities in poverty. We are in part informed by Brady et al.'s (2017) framework for comparing the risk of poverty across populations, which disaggregates disparities in poverty rates into (a) differences in the prevalence of characteristics associated with poverty (i.e., a "prevalence") and (b) differences in the degree of risk associated with a given characteristic (i.e., a "penalty"). Importantly, Brady et al.'s (2017) framework suggests the need to focus on risk factors that are modifiable - and thus potentially influenced by policy interventions - rather than purely ascriptive characteristics (Brady et al. 2017: 742). We therefore focus on five such dimensions of risk: parental age, family structure, parental education, family employment, and place of residence.

Parental age is expected to be inversely associated with the risk of poverty. Poverty rates are particularly high for young parents, especially teenagers and those in their early twenties (Kearney \& Levine 2012). These are the ages at which earnings tend to be lowest, and thus parents least likely to be able to meet the additional income needs associated with a new child. The transition to adulthood is also significantly modified by immigrant generation. For example, Rumbaut and Komaie (2010) find that first generation immigrants are much more likely to have children in their early adult years (56\%), compared to both the second (31\%) and third generations $(38 \%)$.

Family structure is correlated with child poverty risk, in part because single headship constrains family labor supply. Family structure may also capture poverty risks associated with gender discrimination, such as the compounded disadvantage that single mothers may face vis-àvis single fathers (Kramer et al. 2016). Patterns of marriage and cohabitation have been shown to 
vary across immigrant generations, with higher rates of marriage typically — but not alwaysobserved among the earliest generations (Brown et al. 2008; Lichter et al. 2005; Turner \& Thiede 2016). For example, while first-generation Hispanic immigrants have high rates of marriage, those in the second and third+ generations have a noted "retreat from marriage" and more closely resemble the declining marriage rates of the U.S. population at large (Oropesa \& Landale 2004). Generation status is also correlated with family structure at birth. ${ }^{4}$ For instance, in the early 2000s, 37.1 percent of Mexican-American second-generation children and 46.5 percent of the third+ generation were born to unmarried mothers (vs. 22.5\% among non-Hispanic white children). It is also worth noting that generational differences also exist regarding family size, with firstgeneration Hispanic individuals more likely to live with extended kin than U.S.-born peers (Van Hook \& Glick 2007).

Parental education likely affects child poverty risk through employment, job quality, and wages. Given increased matching on education among partners (i.e., assortative mating; Smith et al. 2014), education may also influence poverty by affecting the probability that one's spouse or cohabitating partner is employed and earning above-poverty wages. Prior studies demonstrate significant inter-generational disparities within the Hispanic population. For example, in 2008, only 4.2 percent of first-generation Mexican adults had a college education, compared to 14.8 percent of second-generation individuals (Rumbaut and Komie 2010). Evidence also suggests that these patterns vary by race and ethnicity, with first- and second-generation Mexican-American young adults being less likely to have graduated college than comparable immigrant groups from south and east Asia (Rumbaut and Komie 2010).

\footnotetext{
${ }^{4}$ However, much of these generation differences in marriage rates and unmarried birth rates are likely attributable to educational differences between generations (Glick et al. 2006; Glick 2010).
} 
Employment is the main determinant of family income, and therefore an important correlate of child poverty (Baker 2015). Although employment—even full-time, year-round effort—is sometimes insufficient to lift a family out of poverty (Brady et al. 2010; Thiede et al. 2015), families characterized by unemployment and underemployment face exceptionally high rates of poverty. ${ }^{5}$ Differences in employment between native- and foreign-born adults have been welldocumented. For example, Gonzalez-Barrera and Lopez (2013) show that the unemployment rate in the early 2010s was much higher among native-born Mexican-origin adults (14.1\%) than their foreign-born peers $(10.3 \%)$. There is a similar disparity regarding full-time work (Acevdeo-Garcia et al. 2010; Slack and Jensen 2007). ${ }^{6}$ For example, Rumbaut and Komaie (2010) find that firstgeneration young adults (18-34 years) are more likely to be fully employed (62\%) compared than their second-generation peers (55\%). Likewise, recent estimates show that foreign-born adults from nearly all places of origin work a greater share of the weeks per year than native-born adults (National Academies of Sciences 2017).

Finally, place of residence may affect children's poverty risk by shaping the economic opportunity structure available to parents (Chetty et al. 2014; Cotter 2002). The cost of living, safety net eligibility, and benefit generosity also vary systematically between places, which affects wellbeing and disposable income (Renwick 2011). Such differences can also influence estimates of poverty when using measures that capture such costs and resources, as we do in this paper. Spatial assimilation models predict inter-generational changes in the types of places in which families reside, with neighborhood quality and socioeconomic attainment positively associated

\footnotetext{
5 The relationship between the abovementioned risk factors and child poverty may operate in part through employment. However, we also expect the influence of employment to operate independently of these other risk factors.

${ }^{6}$ Immigrant generation also effects self-rated health, with first generation immigrants having higher averages of selfrated health relative to second and third generation individuals. These differences have direct implications on disability status and likelihood of working full-time (Acevdeo-Garcia et al. 2010).
} 
with immigrant generation (Alba \& Logan 1991; Alba \& Nee 2009; Denton \& Massey 1988). However, such models do not typically account for differences in costs of living. They have also been complicated in recent decades by immigrants' increasing propensity to bypass traditional gateway destinations and the corresponding emergence of new, disproportionately rural immigrant destinations (Crowley et al. 2006; Jones 2019; Lichter \& Johnson 2009; Lichter et al. 2012; Marrow 2020).

In addition to differences across immigrant generations in the prevalence of risk factors, the penalties of these five risk factors may vary systematically across groups (Brady et al. 2018). For instance, associations with parental education may vary across immigrant generations given real or perceived differences in the quality of education received internationally versus domestically (Clark \& Jaeger 2006; Gonzalez 2003; Kaushal 2011). Likewise, the effects of family employment may vary due to inter-generational differences in wages (Massey \& Gelatt 2010); and the effects of place of residence may vary given geographic differences in safety net eligibility and utilization among foreign-born children and native-born children of foreign-born parents (Bitler \& Hoynes 2011; Heinrich 2018). In addition to these and other examples supported by prior research, differences in such penalties may reflect inter-generational disparities in contextual factors and individual characteristics that cannot be easily observed in census and labor-force survey data used here and elsewhere in the literature. While there is strong rationale to expect systematic differences in penalties, such patterns make it difficult to develop a priori hypotheses about the exact nature of these patterns. We therefore consider this issue an empirical question. 


\section{Research objectives}

The overall goals of this paper are to estimate differences in poverty rates across immigrant generations among Hispanic children, to explain the sources of these differences, and to compare the degree of, and explanations for, these differences between Hispanic children and members of other large ethno-racial groups. We address three specific objectives. First, we produce estimates of poverty rates for Hispanic children in each of four immigrant generations (as defined below). Second, we compare the prevalence of five sets of risk factors, and the magnitude of risk associated with each, across generations. As outlined above, we focus on parental age, family structure, parental education, family employment, and place of residence. Third, we examine the intersection of race and immigrant generation by conducting comparable analyses of poverty risks among children in other major ethno-racial groups.

\section{Data}

We draw on microdata from the March Supplement of the Current Population Survey (CPS), which is based on a nationally-representative sample of approximately 60,000 households and is the primary source of labor force statistics for the United States. The March Supplement includes detailed information on prior-year income and employment and is among the most frequently used source of data for research on work and poverty. The CPS is the most appropriate source of information for the proposed study because it includes (a) all of the information needed to calculate the Supplemental Poverty Measure (SPM) and (b) data on parents' country of birth. The latter allows us to measure children's immigrant generation regardless of whether a parent(s) resided with the child at the time of the survey. 
We compile files from the 2014 through 2018 CPS using the Integrated Public Use Microdata Series (IPUMS) (Flood et al. 2017). This time period spans the five most recent waves of the March Supplement that were available at the time of analysis. The analytic sample is restricted to individuals aged 17 years and younger at the time of the survey. Given the sampling structure of the CPS, some children will be observed twice (in consecutive samples). We include observations from all rotating groups, and as such cases should be interpreted as person-period observations. We account for these repeated observations of individuals by clustering on a unique individual identifier produced by IPUMS (Flood et al. 2017). The analytic sample includes a total of 228,979 unweighted person-year observations. ${ }^{7}$

\section{Measures}

The outcome of interest is a given child's poverty status, which we measure using the U.S. Census Bureau's Supplemental Poverty Measure (SPM). Unlike the U.S. government's official poverty measure (OPM), the SPM accounts for non-cash transfers, taxes and tax credits, and geographyspecific costs of living. It also includes cohabitating partners, foster children, and non-attached children under age 15 in family size calculations. Further, the SPM uses a different basket of items and cost calculations to determine poverty thresholds than the OPM, the latter of which uses a now decades-old formula (Meyer \& Sullivan 2012; Wimer et al. 2016a; Wimer et al. 2016b). The SPM is particularly advantageous for our purposes since it facilitates analyses that account for the

\footnotetext{
7 All analyses are weighted using the March Supplement-specific person weight. In the instance that a child was classified as a household head themselves $(n=586)$, they were removed from the analysis.
} 
welfare effects of non-traditional family structures (i.e., cohabitation), place of residence, and safety net programs, all of which are correlated with nativity and race..$^{8,9}$

Our primary stratifying variable is immigrant generation, which we measure using the following four-category typology: (1) foreign-born children ${ }^{10}$; (2) native-born children with two foreign-born parents; (3) native-born children with one foreign-born parent; and (4) native-born children with native-born parents. ${ }^{11}$ Category (1) comprises what is often referred to as the first generation, categories (2) and (3) the second generation, and category (4) the third+ generation. We further stratify children based on race and ethnicity, restricting our main analyses to a sample of Hispanic children. We then conduct additional comparative analyses among the non-Hispanic black (Black), non-Hispanic Asian (Asian), and non-Hispanic white (White) populations, respectively.

As discussed above, we focus on five sets of risk factors. The first is low parental age, which we define as children residing in families headed by adults aged 24 years and younger. We estimate the penalty of this risk factor relative to children in families headed by adults aged 25 to 34 years. We include additional controls to account for children with family heads aged 34 to 44 years, 45 to 54 years, and $55+$ years, respectively. The second factor is family structure, with residence in a family with an unmarried head being the primary risk factor of interest. We

\footnotetext{
${ }^{8}$ Thiede and Brooks (2018) demonstrate immigrant generation disparities in poverty rates vary greatly when using the OPM versus the SPM; and that the SPM likely better-accounts for compositional differences between immigrant groups such as geography and the availability or use of set net programs.

${ }^{9}$ The SPM family units differ from the families used to calculate the official poverty measure. SPM families include cohabitating partners, foster children, and all children under 15 with no identifiable relatives in the household.

${ }^{10}$ This group includes children who are both foreign born non-citizens, and foreign-born naturalized citizens. Although there are compositional differences between these two subgroups, these sub-populations are combined in this analysis due to the relatively small sample size of foreign-born naturalized citizens. See appendix for supplementary analysis of the differences between first-generation citizens and non-citizens.

${ }^{11}$ This category includes children who were born abroad to U.S.-citizen parents.
} 
distinguish between family heads that are married; cohabitating; divorced, separated or widowed; and single, never married.

The third risk factor is low levels of employment among adult family members. Adult work is defined as the average number of full time equivalents (FTEs; 1 FTE $=1,750$ hours) worked by all working-age (ages 24-64 years) adult members of the SPM family unit during the calendar year prior to the CPS. ${ }^{12,13}$ We then construct an indicator that distinguishes between families with less than 0.5 FTE of workers per adult relative to those with 0.5 FTE or more workers per adult. The fourth risk factor is low parental education, defined as when a child's family head did not earn a high school degree. We measure the penalty associated with this risk relative to children of family heads with a high school degree; and also include controls to respectively account for family heads with an associate's degree and a bachelor's degree or higher ${ }^{14}$.

The fifth and final risk factor is place of residence, as defined by whether one resides in a (a) new, established, or other immigrant destination and (b) a metropolitan or non-metropolitan county. County metropolitan status is defined using the Office of Management and Budget's metropolitan classification system and immigrant destination status is defined at the state level following Massey and Capferro (2008, see appendix Figure A1 for states' destination statuses). Combining information from both variables, we construct and use a seven-category typology of place of residence. ${ }^{15}$

\footnotetext{
${ }^{12}$ We set 1.0 FTE to 1,750 hours since this is the total number of hours worked per year given a 35-hour work week and 50-week work year.

${ }^{13}$ We include the work of all working-age adults under the assumption that the family, as defined by the SPM, is a resource-sharing unit. We exclude adults who are in ages where college attendance is most common and adults who are at or beyond retirement age.

${ }^{14}$ We create head educational group's so that those in the high school degree category includes those with CPS education categories of (1) high school diploma or equivalent, and (2) some college but no degree.

15 These categories include established, nonmetropolitan; new, metropolitan; new, nonmetropolitan; other, metropolitan; other, nonmetropolitan; and all counties without an identifiable metropolitan status.
} 


\section{Methods}

The analysis proceeds as follows. We begin by estimating the rate of poverty among Hispanic children by immigrant generation, estimating the prevalence of all five risk factors for each generation, and quantifying the penalty associated with each factor. We do so by estimating a series of linear probability models that predict children's SPM poverty status as a function of all five risk factors and a set of control variables, stratified by immigrant generation. Controls include child's age (in years), relationship to the family head (distinguishing between child, grandchild, and other relation), family head's sex, family size, and region of residence. ${ }^{16}$

We then quantify the contribution of observed inter-generational differences in the prevalence of risk factors to disparities in child poverty. Specifically, we follow Brady et al. (2017) and produce counterfactual predictions of poverty rates for each immigrant generation under the assumption that these groups had the same distribution of poverty risk factors observed among the third + generation. This modified version of Blinder-Oaxaca decomposition (Blinder 1973; Oaxaca 1973) also allows us to partition each of the respective inter-generational gaps in poverty into the components that can be explained by between-group compositional differences.

Our first set of analyses focus on a sample of Hispanic children, who are the largest group of immigrant children. We then examine patterns among immigrants from other ethno-racial groups given previous evidence of racial differences in the economic circumstances of children, and inter-generational differences therein (Lichter et al. 2005). For example, Asian immigrants tend, on average, to be relatively better off than other immigrant groups (Van Hook 2004; Thiede \& Brooks, 2018), and black immigrant groups are often cited as being advantaged relative to their

\footnotetext{
${ }^{16}$ Note that we estimate a linear regression model and conduct a corresponding linear regression decomposition to facilitate interpretation. We argue that this is a reasonable choice given that child poverty rates are sufficiently high, and thus not at the upper or lower bounds of probability.
} 
native-born counterparts (Thomas 2011). To examine these ethno-racial differences, we compare poverty rates, and the prevalence and penalties of poverty risk factors, of Hispanic immigrant generations to the third+-generation White, Asian, and Black populations. In doing so, we account for the possibility that convergence among Hispanic immigrant generations may still leave some groups of children disadvantaged to other native-born peers.

\section{Results}

Poverty among Hispanic children

We begin by analyzing Hispanic child poverty rates by immigrant generation (Figure 1 and Appendix Table A1). Point estimates of poverty are highest among native-born children with two foreign-born parents (32.1\%) and first-generation children (31.4\%). At more than thirty percent, these rates are exceptionally high by most standards. Poverty rates are more than ten percentage points lower among both second-generation children with one foreign-born parent (20.7\%) and the third+ immigrant generation (19.0\%) — but in both cases remain well above the national average for children during this time period (15.9\%). Overall, the results suggest a bifurcation in poverty between immigrant generation groups, with the first two groups converged around a 30 percent poverty rate and both second-generation children with one foreign-born parent and the third+ generation characterized by poverty rates around 20 percent.

(Figure 1)

Prevalence of poverty risk factors among Hispanic children

We next describe the distribution of five major poverty risk factors across immigrant generations

(Figure 2 and Appendix Table A1). We begin by examining the share of children residing in families headed by a young adult, aged 24 or younger. Second-generation children with one 
foreign-born parent are most likely to reside in such families (7.1\%), followed by third+- $(6.6 \%)$ and first-generation (6.2\%) children. Second-generation children with two foreign-born parents are least likely to reside in a family unit headed by a young adult (5.6\%). The range of prevalence rates across generations is 1.5 percentage points, which is relatively small in absolute terms but proportionately represents approximately 24 to 30 percent of the observed rates.

(Figure 2)

We next consider parental marital status, as proxied by the marital status of the family head. Hispanic children in the first two immigrant generations are least likely to reside in a family headed by a single adult, irrespective of whether that family head had even been married or is cohabitating. Just 29.5 percent of first-generation children and 30.4 percent of second-generation children with two foreign-born parents reside in such families. In contrast, well over one-third of the latter two generations reside in families with unmarried adults as head: 34.5 percent of secondgeneration children with one-foreign born parent and 41.1 percent of the third+ generation reside in such families.

The third risk factor is low parental education; defined as when a family head lacks a high school degree. Over forty percent of first-generation children $(43.1 \%)$ and second-generation children with two foreign-born parents (49.2\%) face the risk of low parental education, and these prevalence rates are more than twenty percentage points higher than observed among secondgeneration children with one foreign-born parent $(23.0 \%)$ and members of the third+ generation $(16.9 \%)$. While this pattern suggests a clear disadvantage among the former two groups, it is worth noting that the share of first-generation children in families with a college-educated head (17.2\%) is comparable to that among the latter two generations (20.1\% and $19.1 \%$, respectively). The prevalence of children with a college-educated family head is considerably lower among second- 
generation children with two foreign-born parents $(8.1 \%)$, who as such appear distinctively disadvantaged with respect to parental education.

Fourth, low family employment is most common among first-generation children (16.9\%), and nearly one percentage-point higher than among any of the other three generation groups. The prevalence of this risk factor is next-highest among third+-generation children (16.0\%), followed by second-generation children with two foreign-born parents (15.8\%) and one foreign-born parent (15.6\%), respectively. These differences are notably small, however, and in many cases may simply reflect sampling error.

Finally, we consider the distribution of children by place of residence. Each type of place may provide opportunities and risks with respect to poverty. However, a working hypothesis is that metropolitan areas in new destinations may be particularly risky for immigrant children (with respect to poverty) given the high costs of living associated with residence in a metropolitan area and the low economic status previously observed among children in new destinations (Lichter et al. 2015). The share of children living in such places is similar for all four groups, falling between 20 and 23 percent. In contrast, the first three generations, so defined, are more likely to reside in metropolitan areas of established destination states (all $\geq 68.0 \%$ ) than members of the third+ generation $(62.3 \%)$. The latter are more likely to reside in non-metropolitan areas, and particularly those in new destination states $(30.6 \%)$.

Penalties of risk factors among Hispanic children

In this next set of analyses, we describe levels and inter-generational differentials in the degree of poverty risk associated with each factor (Figure 3 and Appendix Table A2). With respect to family structure, the penalty of residing in a family headed by a young adult is substantively small and 
statistically non-significant among first-generation children and second-generation children with two foreign-born parents. Among second-generation children with one foreign-born parent and third+-generation children, however, the penalties are statistically significant and substantively meaningful, at 8.1 and 10.1 points respectively. That is, relative to children residing in families headed by adults aged 35-44 years within their own immigrant generations, such children face 8.1 and 10.1 percentage point higher probabilities of poverty, respectively and all else equal.

(Figure 3)

We next consider risks associated with residence in families headed by unmarried adults, a category that we disaggregate into three categories. The first includes family heads who are separated, divorced, or widowed. Children in families with such heads experience elevated poverty risks relative to families with married heads, which range in magnitude from 7.3 to 12.2 points among second-generation children with two and one foreign-born parent, respectively. Children with single, never married family heads also face elevated poverty risk across all generations. The penalty is smallest among first-generation children (8.4 points) and largest among secondgeneration children with one foreign-born parent and third+-generation children (both 13.5 points). Finally, children with a cohabitating family head face poverty risks between 5.6 (third+ generation) and 14.4 (second generation, two foreign-born parents) points higher than peers with a married family head. In addition to inter-generation differences in the magnitude of these penalties, it is worth pointing out that intra-generational patterns of penalties vary qualitatively. For example, among the first generation and second-generation children with two-foreign born parents, the penalty associated with cohabitation is larger than for single, never married family heads; while for the other two groups family head cohabitation is associated with the lowest penalty among the three at-risk groups of interest. 
Third, we find that the penalties associated with low parental education are largest among second-generation children with two foreign-born parents (18.9 points), third+-generation children (17.1 points), and first-generation children (15.9 points). The penalty is lowest among secondgeneration children with one foreign-born parent. At 12.7 points, the latter penalty is more than six percentage points lower than observed among second-generation children with two foreignborn parents.

Fourth, low family employment comes with very high penalties. At more than 40 points across all immigrant generations, the degree of risk associated with this characteristic is by far the highest of the five factors considered here. The specific penalties observed across the four immigrant generations range from 41.4 to 42.6 points among the second and third generations, to a full 47.6 points among first-generation Hispanic children. The implication is that, compared to children in families with adequate family employment — as defined by $\geq 0.5 \mathrm{FTE} /$ per adultchildren in low-employment families face exceptionally high poverty risk.

Finally, we consider the penalties associated with different places of residence. Contrary to our provisional expectations, residence in metropolitan areas of new designation states is associated with lower poverty risk (i.e., a reward, not a penalty) for the first and second immigrant generations. These effects range in magnitude from -4.9 and -5.9 points among second-generation children with one foreign-born parent and first-generation children, respectively, to as large as 8.1 points among second-generation children with two foreign born parents. For the third+ generation, there are no statistically significant penalty (or reward) for residence in metropolitan areas of new destination states relative to such areas in established destinations. Given prior attention to child poverty in new rural destinations, it is also worth noting that residence in nonmetropolitan areas of new destination states is associated with reduced poverty risk-relative to 
metropolitan areas of established destinations - among the first generation and second-generation children with two foreign-born parents.

Decomposing inter-generational poverty differentials among Hispanic children The following analysis of the Hispanic population quantifies the contribution of between-group differences in the prevalence of poverty risk factors to inter-generational disparities in child poverty. Given the schedule of penalties observed for each immigrant generation, we produce counterfactual simulations of the poverty rate for a given group had they been characterized by the same distribution of the five risk factors of interest as the third+ generation. We consider the contribution of each factor individually and then estimate the net effect of all five factors simultaneously. Throughout these analyses, we hold the control variables at their observed means for each generation.

We begin by discussing the contribution of each risk factor on its own terms (Table 1, Figure 4). First, differences in the prevalence of young adult family heads explain very little of the differentials in poverty between the third+ generation and all three immigration generation groups of interest. In each case, the counterfactual poverty rate is within 0.1 percentage points of the group's predicted probably of poverty. Next, we find that the family structure of first- and secondgeneration children has a protective effect on poverty relative to the third+ generation. All three of these groups would have experienced higher rates of poverty than observed if they were characterized by the same distribution of family head marital status as the third+ generation. The absolute differences between the simulated and observed values rate from 0.7 percentage points among second-generation children with one foreign-born parent to 1.2 percentage points among second-generation children with two foreign born parents. In proportional terms, such changes in 
family structure respectively represent 3.4 and 3.8 percent increases over the observed poverty rates.

(Table 1)

(Figure 4)

Third, parental education operates as an important source of disadvantage among firstgeneration children and second-generation children with two foreign-born parents. If firstgeneration children had the same levels of parental education as the third+ generation, they would have experienced a 2.9 percentage point $(9.2 \%)$ lower risk of poverty than was observed. Likewise, second-generation children with two foreign-born parents would have had a poverty risk 4.6 percentage points (14.3\%) lower than observed. In contrast, education explains little of the difference in poverty risk between the third+ generation and second-generation children with one foreign born parent. Our simulation produces a counterfactual poverty rate of 20.3 percent for the latter, just 0.4 percentage points $(1.9 \%)$ lower than observed.

Fourth, inter-generational differences in parental employment play a minor role in the poverty differentials between third+-generation children and both second-generation groups. In each instance, our counterfactual simulations yield estimates that are within 0.2 percentage points of the observed values. Applying third+-generation parental work levels to the first generation yields an estimated poverty rate of 30.9 percent, 0.5 percentage points (1.6\%) lower than what was observed. Low parental employment among the first generation is a modest source of disadvantage relative to the third+ generation. The limited explanatory role of parental work is particularly notable given the large penalty associated with low levels of employment, highlighting the importance of distinguishing between the poverty-generating roles of risk prevalences and penalties. 
Fifth, we simulate child poverty rates for the first two generations assuming they share the same geographic distribution across our immigrant generation typology as the third+ generation. In all three cases, the simulated poverty rate is lower than observed, suggesting place of residence is a source of disadvantage for these groups relative to the third+ generation. Differences between the observed and simulated values range from 0.9 percentage points $(2.8 \%)$ among secondgeneration children with two foreign-born parents to 0.2 percentage points $(1.0 \%)$ among members of the second-generation with one foreign-born parent.

Finally, we consider the net contribution of all five risk factors to child poverty differentials. If first-generation children and second-generation children with two foreign-born parents had the same average characteristics as the third+ generation (as observed here) they would have experienced $2.8(8.9 \%)$ and $4.4(13.7 \%)$ percentage-point lower probabilities of poverty than observed. Overall, then, such compositional differences represent a substantively important source of disadvantage among these two groups relative to the third+ generation. In contrast, if secondgeneration children with one foreign-born parent had the same characteristics as the third generation, their expected probability of poverty would have increased slightly from 20.7 to 20.8 percentage points. This exercise suggests that differences in population characteristics contribute little to modest poverty differentials between these latter two groups.

Inter-generational differences in penalties and prevalences among other ethno-racial groups Our final objective is to understand whether and how the intergenerational patterns of child poverty observed among the Hispanic population above may differ across ethno-racial groups. A full comparison is beyond the scope of this single paper, so we extend the analysis above by producing simulated poverty rates for each Hispanic immigrant generation using the risk factor prevalences 
observed among the third+ generations of non-Hispanic white, non-Hispanic black, and Asian children, respectively. Given the extent of these results, we focus our discussion on the overall, net effect of the five risk factors of interest on child poverty risk. Full results are included in the text and appendix. ${ }^{17}$

We begin by simulating the poverty rate among Hispanic children using the distribution of risk factors as the non-Hispanic white third+ generation (Table 2, Figure 5). If first-generation Hispanic children had the same prevalence of risk factors as third+-generation non-Hispanic white children, their expected poverty rate would fall from 31.4 to 18.4 percent. This hypothetical 13.0 percentage point reduction represents a full 41.4 percent decrease in the observed poverty rate. The population of second-generation Hispanic children with two foreign-born parents would experience an even larger 16 percentage point (49.8\%) reduction in poverty if their distribution of poverty risk factors aligned with third+ generation non-Hispanic whites. Second-generation Hispanic children with one foreign-born parent and third+ generation Hispanic children would experience $9.3(44.9 \%)$ and $8.8(46.3 \%)$ percentage point reductions under such a scenario, respectively. The groups with the greatest inter-generational advantages among the Hispanic population still face important disadvantages relative to non-Hispanic white children.

(Table 2)

(Figure 5)

Applying the distribution of poverty risk factors among the third+ generation of Asian children to the Hispanic child population also results in lower expected poverty rates across all immigrant generations (Figure 6). These differences are slightly less in magnitude than the above simulation that applied the non-Hispanic white population's schedule of risk factors but are

\footnotetext{
${ }_{17}$ Tables showing our analyses of prevalences and penalties for the non-Hispanic white, non-Hispanic black, and Asian populations are included in the appendix.
} 
nonetheless substantively meaningful. For instance, this simulation results in a 13.1 percentage point $(40.1 \%)$ lower expected poverty rate among second-generation Hispanic children with two foreign-born parents, and a 7.3 percentage point (38.4\%) lower expected poverty rate among third+-generation Hispanic children.

(Figure 6)

Finally, we analyze differences between the Hispanic and non-Hispanic black populations (Figure 7). Applying the risk factor distribution of the third+ generation of non-Hispanic black children results in net increases in expected poverty rates among all Hispanic children except members of the second generation with two foreign-born parents. The latter's expected poverty rate declines by 1.2 percentage points (3.7\%) under this simulation, but other groups experience between 0.7 (first generation) and 5.6 percentage point (third+ generation) increases in expected poverty rates. The implication is that, in contrast to the first two simulations, Hispanic children are relatively advantaged in terms of the five risk factors examined here.

(Figure 7)

\section{Discussion and conclusions}

In this paper, we have examined patterns of child poverty across immigrant generations, focusing on the Hispanic population and drawing comparisons with other major ethno-racial groups. Our analyses point to four overall conclusions and have a number of implications for future research. First, Hispanic children face exceptionally high poverty rates overall, but these rates are particularly high among the first generation and second-generation children with two foreign-born parents. These two groups face comparably high poverty rates of approximately 30 percent, while poverty among the latter two generations is at approximately 20 percent. 
Second, the magnitude of poverty risk associated with each of the five factors varies across immigrant generations but in a manner that does not lend itself to broad characterizations. For instance, children in the third+ generation face the lowest penalty for low family work (relative to other Hispanic immigrant generations) but the highest penalty for having young parents. There is nonetheless a clear gradient in the magnitude of penalties across generation groups, with low work having the largest effect, followed by parental education, parental marital status, place of residence, and, finally, parental age.

Third, inter-generational differences in the distribution of risk factors explains non-trivial shares of the poverty differentials between the third+ generation and both the first generation and second-generation children with two foreign-born parents. Differences in family structure are a source of advantage for the latter two groups relative to the third+ generation, but this effect is offset and reversed by disadvantages in terms of parental education. That is, these groups are not uniformly disadvantaged relative to the third+ generation. This analysis also demonstrates that the factors with the largest penalties (e.g., low family employment) are not necessarily the factors that explain the largest share of inter-generational child poverty gaps. Analysts and policymakers should be careful to differentiate between the marginal effects of changing a risk factor and the aggregate impact such a change would have given the baseline distribution of that factor.

Fourth and finally, patterns of poverty across immigrant generations are in part moderated by race and ethnicity. The distribution of risk factors among Hispanic children of all immigrant generations-including the third+-represents a net source of disadvantage when put in the context of the non-Hispanic white and Asian third+ generations. In contrast, most (but not all) generations of Hispanic children face advantages in the distribution of risk factors relative to the non-Hispanic black third+ generation. These findings underscore the need to place analyses of 
inter-generational inequalities within ethno-racial groups in the context of racial and ethnic stratification.

Given rapid demographic change and exceptionally high child poverty rates overall (Shaefer et al. 2018; Smeeding 2016), evidence showing which groups of children are most at risk, and why, is increasingly needed to develop appropriate policy and programmatic interventions. Our results contribute to this knowledge gap and serve as a basis for extensions in future research. One priority is to better-understand whether and how the role of safety net programs varies across immigrant generations, and to unpack whether such differences are driven by disparities in eligibility or utilization (Bean et al. 1997; Heinrich 2018; Jensen 1988). Future research should also prioritize analysis of changes in inter-generation disparities in child poverty over time. How have changes to immigration policy, the safety net, and socioeconomic structure more broadly shaped inter-generational gradients and the assimilation trajectories they may be correlated with? Attention to these and related questions is needed to understand the economic underpinnings of new cohorts of children, who are increasingly diverse along multiple axes. Such evidence can inform policies to ensure growing diversity among youth does not result in increasing fragmentation with respect to socioeconomic conditions during childhood and overall life chances (Lichter 2013). 


\section{References}

Abraído-Lanza, A. F., Echeverría, S. E., \& Flórez, K. R. (2016). Latino immigrants, acculturation, and health: Promising new directions in research. Annual review of public health, 37, 219236.

Acevedo-Garcia, D., Bates, L.M., Osypuk, T.L., \& McArdle, N. (2010). The effect of immigrant generation on self-rated health among US adults 2003-2007. Social Science and Medicine, 71(6), 1161-1172.

Alba, R., \& Foner, N. (2015). Strangers no more: Immigration and the challenges of integration in North America and Western Europe. Princeton University Press.

Alba, R. D., \& Logan, J. R. (1991). Variations on two themes: Racial and ethnic patterns in the attainment of suburban residence. Demography, 28(3), 431-453.

Alba, R., \& Nee, V. (1997). Rethinking assimilation theory for a new era of immigration. International Migration Review, 31(4), 826-874.

Alba, R., \& Nee, V. (2009). Remaking the American mainstream: Assimilation and contemporary immigration. Harvard University Press.

Baker, R. S. (2015). The changing association among marriage, work, and child poverty in the United States, 1974-2010. Journal of Marriage and Family, 77(5), 1166-1178.

Bean, F. D., Van Hook, J. V., \& Glick, J. E. (1997). Country of origin, type of public assistance, and patterns of welfare recipiency among US immigrants and natives. Social Science Quarterly, 432-451.

Bitler, M., \& Hoynes, H. W. (2011). Immigrants, welfare reform, and the US safety net (No. w17667). National Bureau of Economic Research.

Blinder, A. S. (1973). Wage discrimination: Reduced form and structural estimates. Journal of Human Resources, 8(4), 436-455.

Borjas, G. J. (2011). Poverty and program participation among immigrant children. The Future of Children, 21(1), 247-266.

Brady, D., Fullerton, A. S., \& Cross, J. M. (2010). More than just nickels and dimes: A crossnational analysis of working poverty in affluent democracies. Social Problems, 57(4), 559585.

Brady, D., Finnigan, R. M., \& Hübgen, S. (2017). Rethinking the risks of poverty: a framework for analyzing prevalences and penalties. American Journal of Sociology, 123(3), 740-786.

Bradley, R. H., \& Corwyn, R. F. (2002). Socioeconomic status and child development. Annual review of psychology, 53(1), 371-399.

Brown, S. L., Van Hook, J., \& Glick, J. E. (2008). Generational differences in cohabitation and marriage in the US. Population Research and Policy Review, 27(5), 531-550.

Call, M. A., \& Voss, P. R. (2016). Spatio-temporal dimensions of child poverty in America, 1990-2010. Environment and Planning A, 48(1), 172-191.

Chetty, R., Hendren, N., Kline, P., \& Saez, E. (2014). Where is the land of opportunity? The geography of intergenerational mobility in the United States. The Quarterly Journal of Economics, 129(4), 1553-1623.

Clark, M. A., \& Jaeger, D. A. (2006). Natives, the foreign-born and high school equivalents: New evidence on the returns to the GED. Journal of Population Economics, 19(4), 769-793.

Crowley, M., Lichter, D. T., \& Qian, Z. (2006). Beyond gateway cities: Economic restructuring and poverty among Mexican immigrant families and children. Family Relations, 55(3), 345-360.

Cotter, D. A. (2002). Poor people in poor places: Local opportunity structures and household 
poverty. Rural Sociology, 67(4), 534-555.

Denton, N. A., \& Massey, D. S. (1988). Residential segregation of blacks, Hispanics, and Asians by socioeconomic status and generation. Social Science Quarterly, 69(4), 797.

Drake, B., \& Rank, M. R. (2009). The racial divide among American children in poverty: Reassessing the importance of neighborhood. Children and Youth Services Review, 31(12), 1264-1271.

Duncan, G. J., Ziol-Guest, K. M., \& Kalil, A. (2010). Early-childhood poverty and adult attainment, behavior, and health. Child Development, 81(1), 306-325.

Duncan, G. J., Yeung, W. J., Brooks-Gunn, J., \& Smith, J. R. (1998). How much does childhood poverty affect the life chances of children?. American sociological review, 406-423.

Eggebeen, D. J., \& Lichter, D. T. (1991). Race, family structure, and changing poverty among American children. American Sociological Review, 801-817.

Flood, S., King, M., Ruggles, S., \& Warren. J.R. (2019). Integrated public use microdata series, Current Population Survey: Version 6.0. [dataset]. University of Minnesota, Minneapolis, $\mathrm{MN}$

Frey, W.H. (2019). Less than Half of US children under 15 are white, census shows. The Brookings Institution. Published June 24, 2019. Available at https://www.brookings.edu/research/less-than-half-of-us-children-under-15-are-whitecensus-shows/

Glick, J. E., Ruf, S. D., White, M. J., \& Goldscheider, F. (2006). Educational engagement and early family formation: Differences by ethnicity and generation. Social Forces, 84(3), 1391-1415.

Glick, J. E. (2010). Connecting complex processes: A decade of research on immigrant families. Journal of Marriage and Family, 72(3), 498-515.

Gonzalez, A. (2003). The education and wages of immigrant children: the impact of age at arrival. Economics of Education Review, 22(2), 203-212.

Gonzalez-Barrera, A., \& Lopez, M. H. (2013). A demographic portrait of Mexican-origin Hispanics in the United States. Washington, DC: Pew Hispanic Center.

Heinrich, C. J. (2018). Presidential address: "A thousand petty fortresses": Administrative burden in US immigration policies and its consequences. Journal of Policy Analysis and Management, 37(2), 211-239.

Humes, K., Jones, N. A., \& Ramirez, R. R. (2011). Overview of race and Hispanic origin, 2010. US Department of Commerce, Economics and Statistics Administration, US Census Bureau.

Jensen, L. (1988). Patterns of immigration and public assistance utilization, 1970-1980. International Migration Review, 51-83.

Jensen, L., \& Chitose, Y. (1994). Today's second generation: Evidence from the 1990 US Census. International Migration Review, 28(4), 714-735.

Johnson, K. M., \& Lichter, D. T. (2008). Natural increase: A new source of population growth in emerging Hispanic destinations in the United States. Population and Development Review, 34(2), 327-346.

Jones, J. (2019). From open doors to closed gates: Intragenerational reverse incorporation in new immigrant destinations. International Migration Review, 53(4), 1002-1031.

Kaushal, N. (2011). Earning trajectories of highly educated immigrants: Does place of education matter?. ILR Review, 64(2), 323-340. 
Kearney M. S., Levine P. B. (2012). Why is the teen birth rate in the United States so high and why does it matter? Journal of Economic Perspectives, 26(2): 141-163

Kramer, K. Z., Myhra, L. L., Zuiker, V. S., \& Bauer, J. W. (2016). Comparison of poverty and income disparity of single mothers and fathers across three decades: 1990-2010. Gender Issues, 33(1), 22-41.

Lichter, D. T. (2013). Integration or fragmentation? Racial diversity and the American future. Demography, 50(2), 359-391.

Lichter, D. T., \& Johnson, K. M. (2009). Immigrant gateways and Hispanic migration to new destinations. International Migration Review, 43(3), 496-518.

Lichter, D. T., Johnson, K. M., Turner, R. N., \& Churilla, A. (2012). Hispanic assimilation and fertility in new US destinations. International Migration Review, 46(4), 767-791.

Lichter, D. T., Qian, Z., \& Crowley, M. L. (2005). Child poverty among racial minorities and immigrants: Explaining trends and differentials. Social Science Quarterly, 86(s1), 10371059.

Lichter, D. T., Sanders, S. R., \& Johnson, K. M. (2015). Hispanics at the starting line: poverty among newborn infants in established gateways and new destinations. Social Forces, 94(1), 209-235.

Marrow, H. B. (2020). Hope turned sour: second-generation incorporation and mobility in US new immigrant destinations. Ethnic and Racial Studies, 43(1), 99-118.

Massey, D. S., \& Capoferro, C. (2008). The geographic diversification of American immigration. New faces in new places: The changing geography of American immigration, 25-50.

Massey, D. S., \& Gelatt, J. (2010). What happened to the wages of Mexican immigrants? Trends and interpretations. Latino Studies, 8(3), 328-354.

Meyer, B. D., \& Sullivan, J. X. (2012). Identifying the disadvantaged: official poverty, consumption poverty, and the new supplemental poverty measure. The Journal of Economic Perspectives, 26(3), 111-135.

National Academies of Sciences. (2016). The integration of immigrants into American society. National Academies Press.

National Academies of Sciences. (2017). The economic and fiscal consequences of immigration. National Academies Press.

Oaxaca, R. (1973). Male-female wage differentials in urban labor markets. International Economic Review, 14(3), 693-709.

Oropesa, R.S., \& Landale, N.S. (1997). Immigrant legacies: Ethnicity, generation, and children's familial and economic lives. Social Science Quarterly, 78(2): 399-416

Oropesa, R. S., \& Landale, N. S. (2004). The future of marriage and Hispanics. Journal of Marriage and family, 66(4), 901-920.Park, J., \& Myers, D. (2010). Intergenerational mobility in the post1965 immigration era:

Estimates by an immigrant generation cohort method. Demography, 47(2), 369-392.

Parolin, Z., \& Brady, D. (2019). Extreme child poverty and the role of social policy in the United States. Journal of Poverty and Social Justice, 27(1), 3-22.

Parrado, E. A., \& Morgan, S. P. (2008). Intergenerational fertility among Hispanic women: New evidence of immigrant assimilation. Demography, 45(3), 651-671.

Qian, Z., \& Qian, Y. (2019). Generation, education, and intermarriage of Asian Americans. Journal of Ethnic and Migration Studies, 1-16.

Renwick, T. (2011). Geographic Adjustments of Supplemental Poverty Measure Thresholds: Using the American Community Survey Five-Year Data on Housing Costs. SEHSD 
Working Paper Number 2011-21.

Rumbaut, R. G., \& Portes, A. (2001). Ethnicities: Children of immigrants in America. Univ of California Press.

Rumbaut, R.G., \& Komaie, G. (2010). Immigration and Adult Transitions. The Future of Children 20(1), 43-66.

Shaefer, H. L., Collyer, S., Duncan, G., Edin, K., Garfinkel, I., Harris, D., ... \& Yoshikawa, H. (2018). A universal child allowance: A plan to reduce poverty and income instability among children in the United States. RSF: The Russell Sage Foundation Journal of the Social Sciences, 4(2), 22-42.

Slack, T., \& Jensen, L. (2007). Underemployment across immigrant generations. Social Science Research, 36(4), 1415-1430.

Smeeding, T., \& Thévenot, C. (2016). Addressing child poverty: How does the United States compare with other nations? Academic Pediatrics, 16(3), S67-S75.

Smith, J. A., M. McPherson, \& L. Smith-Lovin. (2014). Social Distance in the United States: Sex, Race, Religion, Age, and Education Homophily among Confidants, 1985 to 2004. American Sociological Review 79(3): 432-56.

Thiede, B., \& Brooks, M. M. (2018). Child poverty across immigrant generations in the United States, 1993-2016: Evidence using the official and supplemental poverty measures. Demographic Research, 39, 1065-1080.

Thiede, B. C., Kim, H., \& Slack, T. (2017). Marriage, Work, and Racial Inequalities in Poverty: Evidence From the United States. Journal of Marriage and Family, 79(5), 1241-1257.

Thiede, B. C., Lichter, D. T., \& Sanders, S. R. (2015). America's working poor: Conceptualization, measurement, and new estimates. Work and Occupations, 42(3), 267-312.

Thiede, B. C., Sanders, S. R., \& Lichter, D. T. (2017). Born Poor? Racial Diversity, Inequality, and the American Pipeline. Sociology of Race and Ethnicity. Forthcoming.

Timberlake, J. M. (2007). Racial and ethnic inequality in the duration of children's exposure to neighborhood poverty and affluence. Social Problems, 54(3), 319-342.

Thomas, K.J. (2011). Familial influences on poverty among young children in black immigrant, U.S.-born black, and nonblack immigrant families. Demography, 48(2), 437-460

Tran, C., \& Valdez, N.M. (2017). Second-Generation Decline or Advantage? Latino Assimilation in the Aftermath of the Great Recession. International Migration Review, 51(1): 155-190.

Turner, R. N., \& Thiede, B. (2016). Mexican-American Educational Stagnation: The Role of Family-Structure Change. International Migration Review. Forthcoming.

U.S. Census Bureau. (2019). Population Estimates Show Aging Across Race Groups Differs. Published June 20, 2019. Washington, DC: Available at census.gov/newsroom/pressreleases/2019/estimates-characteristics.html

Van Hook, J., Brown, S. I., \& Kwenda, M. N. (2004). A decomposition of trends in poverty among children of immigrants. Demography, 41(4), 649-670.

Van Hook, J., \& Glick, J.E. (2007). Immigration and Living Arrangements: Moving beyond Economic Need versus Acculturation. Demography, 44(2), 225-249

Voss, P. R., Long, D. D., Hammer, R. B., \& Friedman, S. (2006). County child poverty rates in the US: a spatial regression approach. Population Research and Policy Review, 25(4), 369391.

Wimer, C., Fox, L., Garfinkel, I., Kaushal, N., \& Waldfogel, J. (2016a). Progress on poverty? New estimates of historical trends using an anchored supplemental poverty measure. Demography, 53(4), 1207-1218. 
Wimer, C., Nam, J., Waldfogel, J., \& Fox, L. (2016b). Trends in child poverty using an improved measure of poverty. Academic Pediatrics, 16(3), S60-S66.

Woods, T., \& Hanson, D. (2016). Demographic trends of children of immigrants. Urban Institute Brief. Urban Institute. 
Tables

Table 1 Counterfactual predictions of poverty (SPM) using Hispanic third+ generation risk distribution among Hispanic children, by immigrant generation Original Predictions

Using Counterfactual Distribution

Education

Age Groups Marital Groups

Groups

Geography

First

Second, two foreign-born parents

Second, one foreign-born parent

0.315

0.321

0.321

0.207

0.207

0.325

0.333

0.190

0.214

0.285

0.274

Work Groups

Groups

0.312

0.309

0.322
0.209

0.205

All

Third+

---

$---$

$---$

0.286

0.277

0.208

$---$ 
Table 2 Counterfactual predictions of poverty (SPM) using third+ generation risk distribution among Hispanic children, by immigrant generation

\begin{tabular}{|c|c|c|c|c|c|c|c|}
\hline & Original Predictions & & & hird+ Generation & White Distributi & & \\
\hline & & Age Groups & Marital Groups & Education Groups & Work Groups & Geography Groups & All \\
\hline First & 0.314 & 0.313 & 0.308 & 0.256 & 0.277 & 0.283 & 0.184 \\
\hline Second, two foreign-born parents & 0.321 & 0.317 & 0.310 & 0.241 & 0.294 & 0.283 & 0.161 \\
\hline Second, one foreign-born parent & 0.207 & 0.200 & 0.193 & 0.180 & 0.181 & 0.190 & 0.114 \\
\hline Third+ (Hispanic) & 0.190 & 0.186 & 0.170 & 0.162 & 0.161 & 0.180 & 0.102 \\
\hline Third+ (White) & 0.087 & --- & --- & --- & --- & --- & --- \\
\hline & Original Predictions & & & Third+ Generation & Asian Distributi & & \\
\hline & & Age Groups & Marital Groups & Education Groups & Work Groups & Geography Groups & All \\
\hline First & 0.314 & 0.310 & 0.306 & 0.256 & 0.288 & 0.306 & 0.213 \\
\hline Second, two foreign-born parents & 0.321 & 0.312 & 0.310 & 0.240 & 0.304 & 0.309 & 0.190 \\
\hline Second, one foreign-born parent & 0.207 & 0.197 & 0.189 & 0.180 & 0.191 & 0.201 & 0.129 \\
\hline Third+ (Hispanic) & 0.190 & 0.187 & 0.166 & 0.160 & 0.171 & 0.190 & 0.117 \\
\hline Third+ (Asian) & 0.117 & --- & --- & --- & --- & --- & --- \\
\hline & Original Predictions & & & Third+ Generation & Black Distributi & & \\
\hline & & Age Groups & Marital Groups & Education Groups & Work Groups & Geography Groups & All \\
\hline First & 0.314 & 0.318 & 0.344 & 0.279 & 0.348 & 0.291 & 0.321 \\
\hline Second, two foreign-born parents & 0.321 & 0.211 & 0.361 & 0.267 & 0.356 & 0.291 & 0.309 \\
\hline Second, one foreign-born parent & 0.207 & 0.155 & 0.247 & 0.199 & 0.244 & 0.192 & 0.257 \\
\hline Third+ (Hispanic) & 0.190 & 0.258 & 0.223 & 0.183 & 0.225 & 0.184 & 0.246 \\
\hline Third+ (Black) & 0.258 & --- & --- & --- & --- & --- & --- \\
\hline
\end{tabular}




\section{Figures}

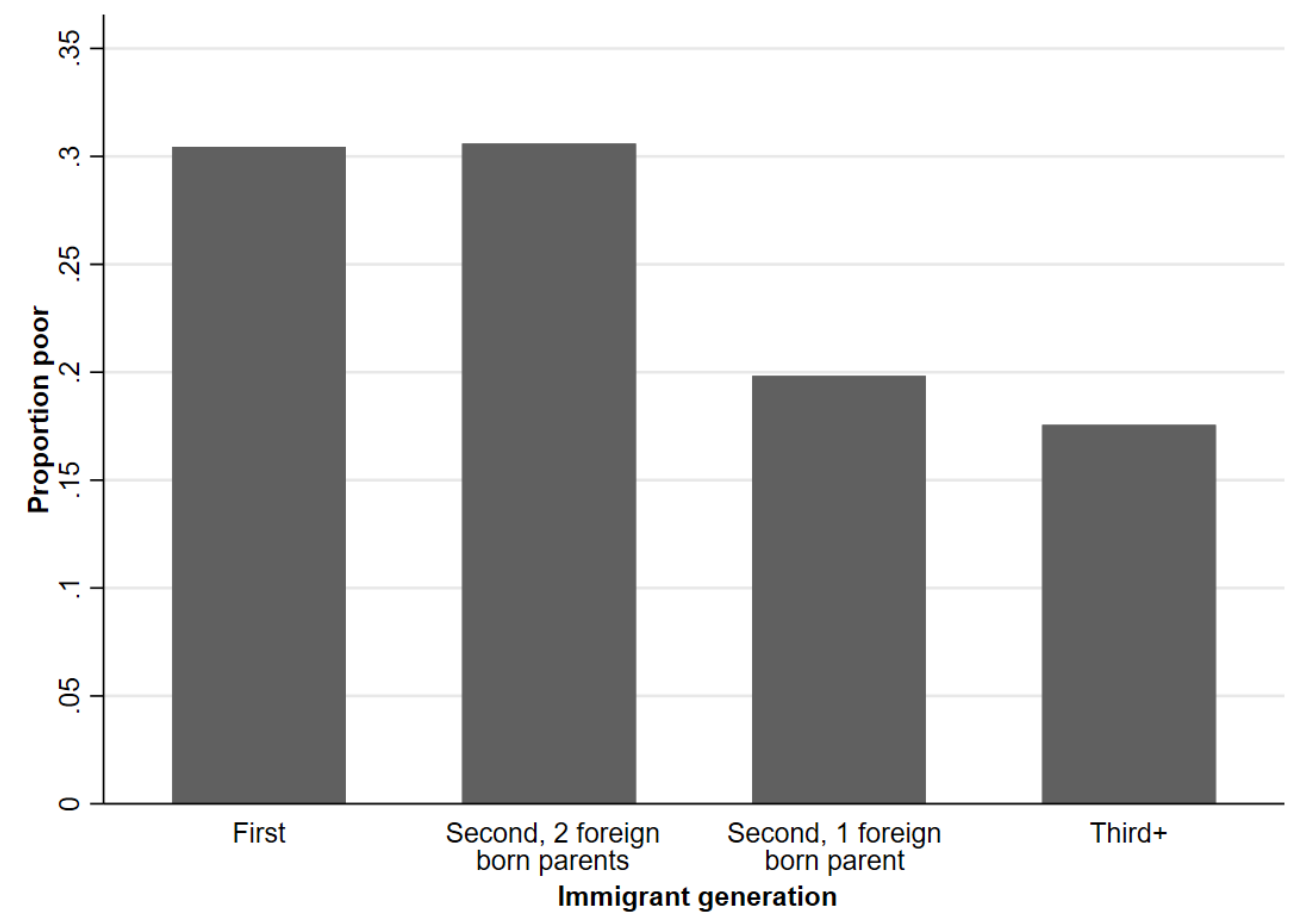

Figure 1 SPM poverty rate of Hispanic children by immigrant generation 

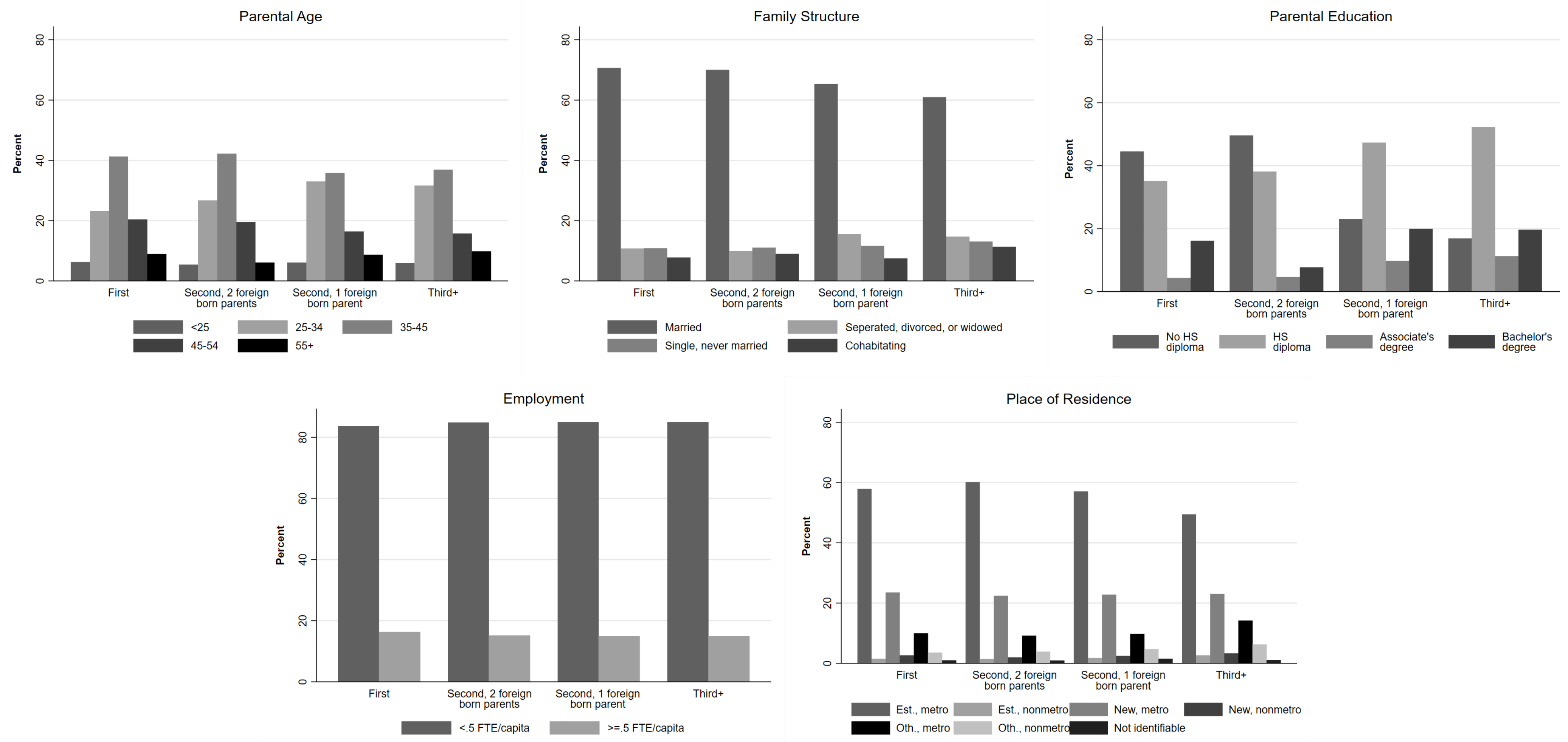

Figure 2 Prevalence of poverty risks among Hispanic children, by immigrant generation 

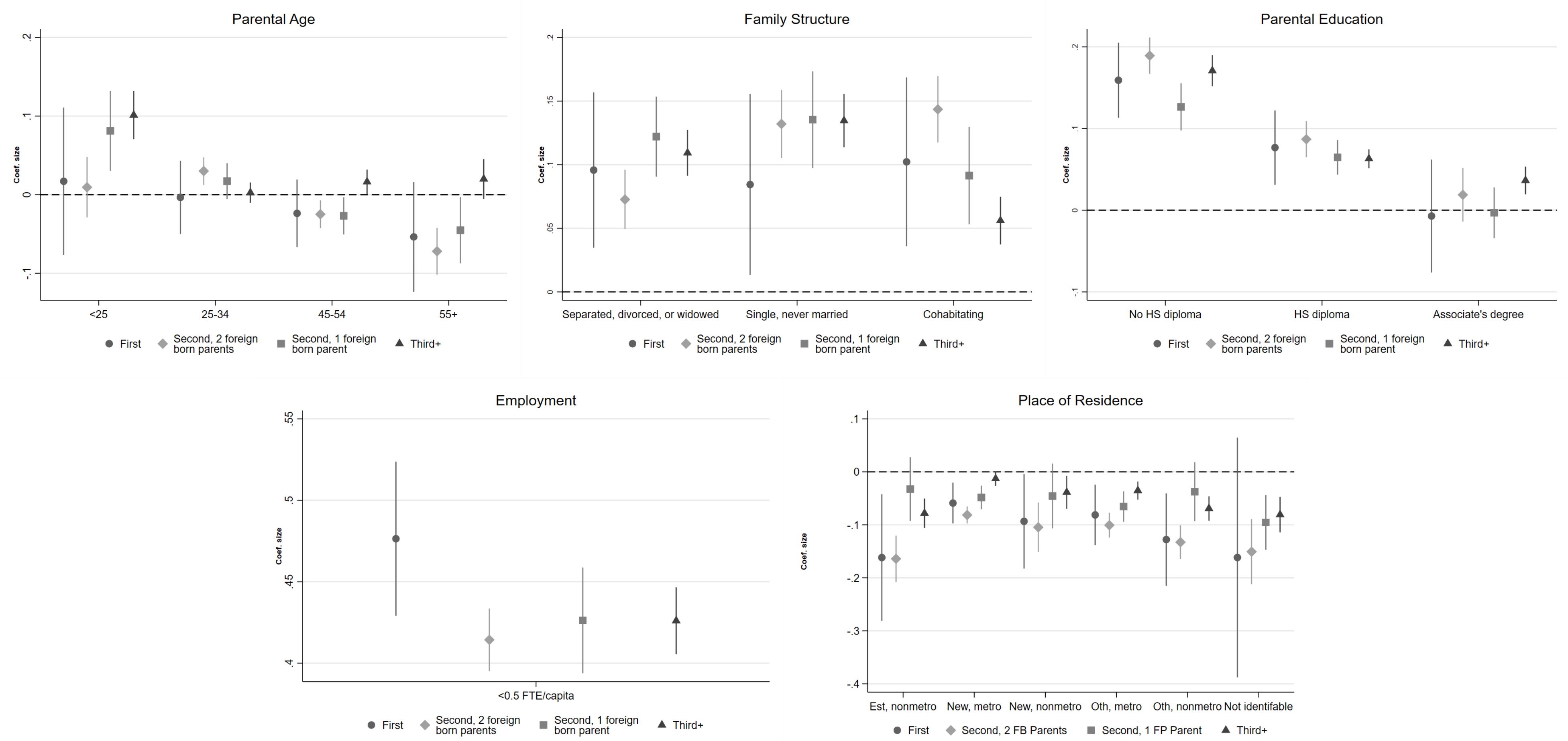

Figure 3 Penalties of poverty risks among Hispanic children, by immigrant generation 


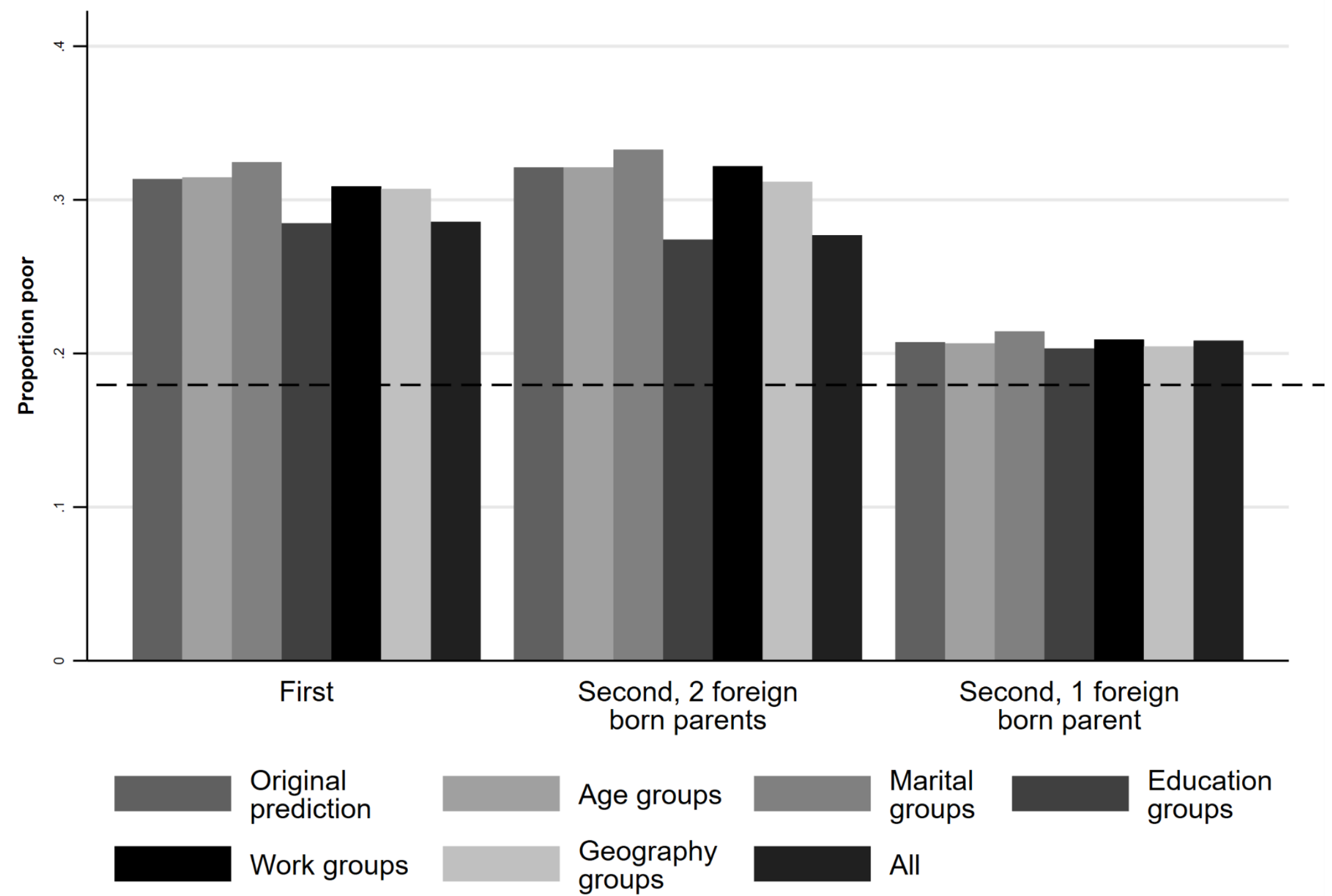

Note: Horizontal line represents SPM prediction for Hispanic third+ generation group

Figure 4 Counterfactual predictions of poverty (SPM) using Hispanic third+ generation risk prevalences among Hispanic children, by immigrant generation 


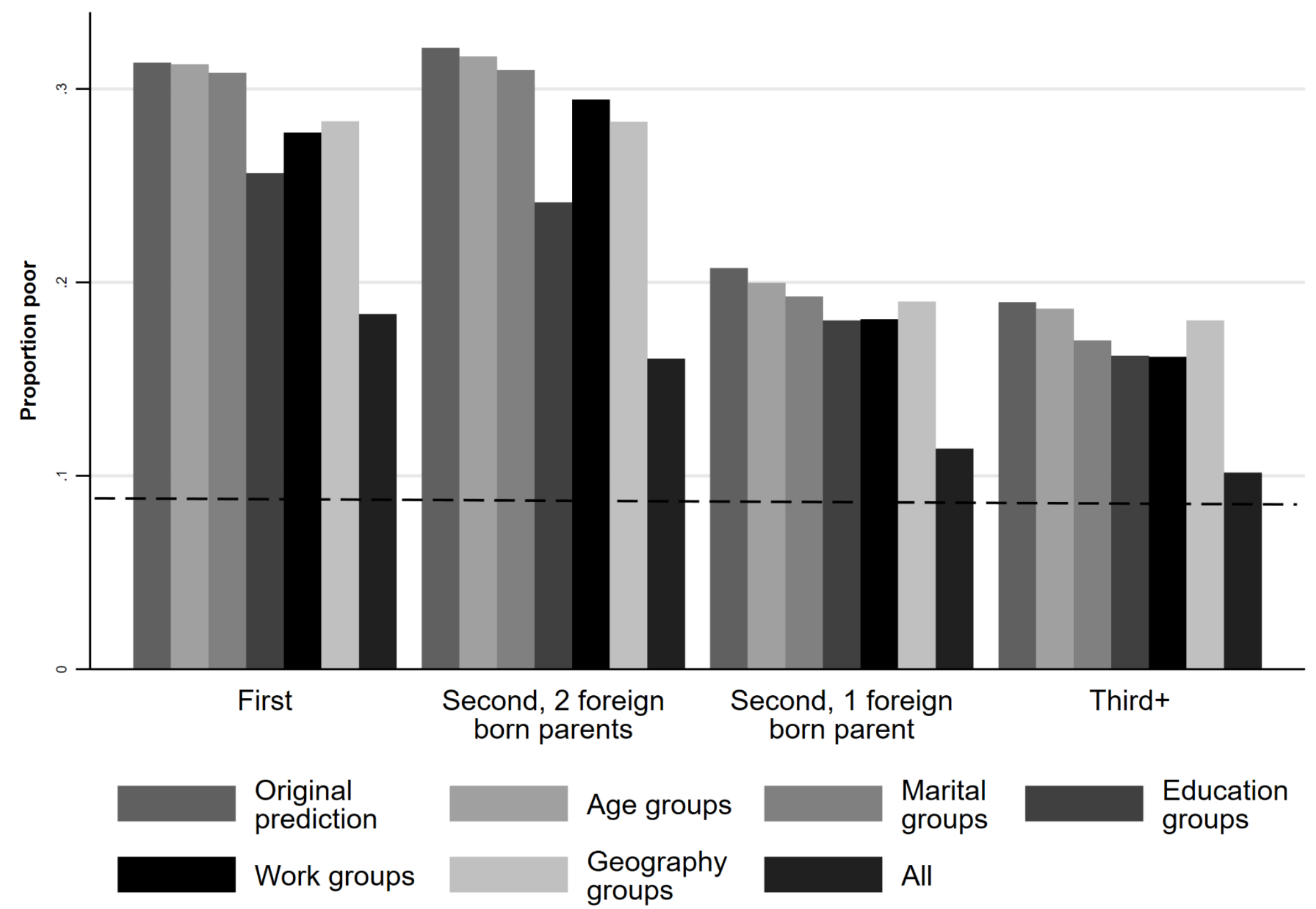

Note: Horizontal line represents SPM prediction for White third+ generation group

Figure 5 Counterfactual predictions of poverty (SPM) using White third+ generation risk prevalences among Hispanic children, by immigrant generation 


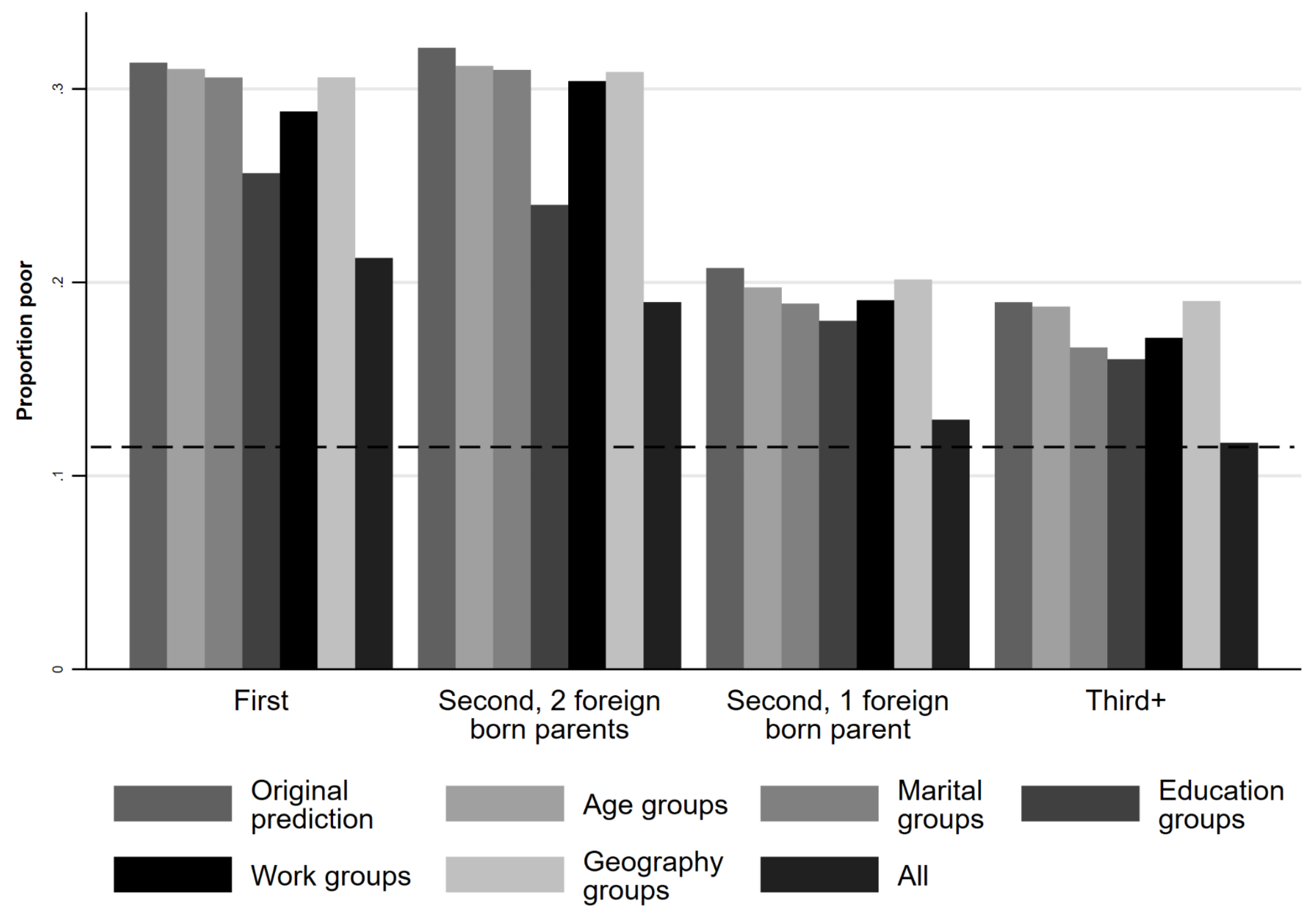

Note: Horizontal line represents SPM prediction for Asian third+ generation group

Figure 6 Counterfactual predictions of poverty (SPM) using Asian third+ generation risk prevalences among Hispanic children, by immigrant generation 


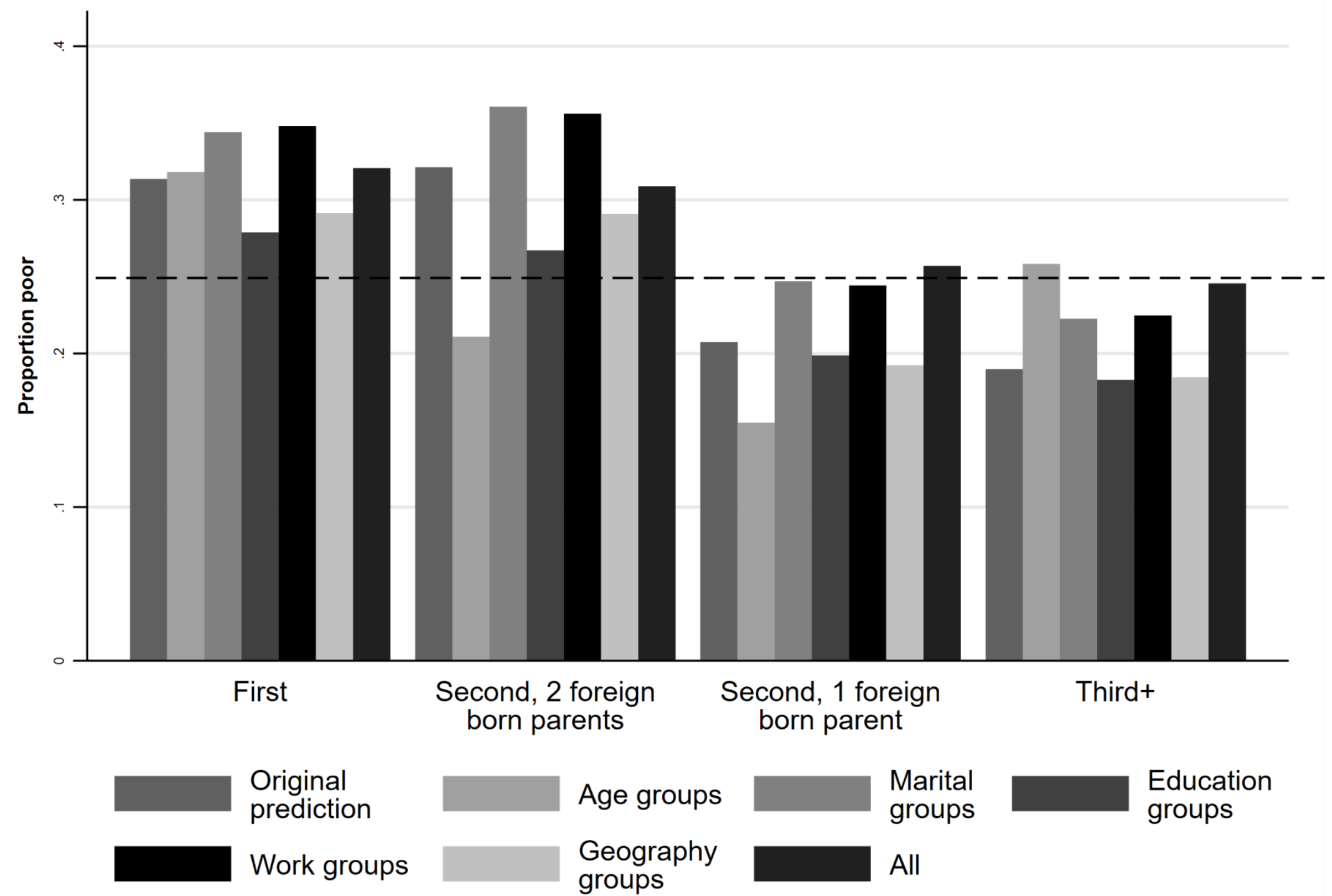

Note: Horizontal line represents SPM prediction for Black third+ generation group

Figure 7 Counterfactual predictions of poverty (SPM) using Black third+ generation risk prevalences among Hispanic children, by immigrant generation 


\section{Appendix}

Table A1 Description of sample (Hispanic only), by immigrant generation

\begin{tabular}{|c|c|c|c|c|}
\hline & First & $\begin{array}{l}\text { Second, Two } \\
\text { Foreign-Born } \\
\text { Parents }\end{array}$ & $\begin{array}{c}\text { Second, One } \\
\text { Foreign-Born } \\
\text { Parent }\end{array}$ & Third+ \\
\hline \multicolumn{5}{|l|}{ Poverty } \\
\hline SPM poverty status (\%) & 0.314 & 0.321 & 0.207 & 0.190 \\
\hline \multicolumn{5}{|l|}{ Child characteristics } \\
\hline Age & $\begin{array}{l}11.699 \\
(4.453)\end{array}$ & $\begin{array}{l}8.535 \\
(5.048)\end{array}$ & $\begin{array}{l}7.779 \\
(5.051)\end{array}$ & $\begin{array}{l}7.983 \\
(5.174)\end{array}$ \\
\hline \multicolumn{5}{|l|}{ Relationship to SPM unit head (\%) } \\
\hline 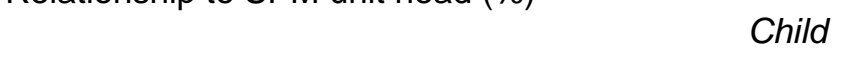 & 0.824 & 0.888 & 0.865 & 0.839 \\
\hline Grandchild & 0.039 & 0.036 & 0.090 & 0.108 \\
\hline Other & 0.137 & 0.076 & 0.045 & 0.052 \\
\hline \multicolumn{5}{|l|}{$\begin{array}{l}\text { SPM unit head characteristics } \\
\text { SPM unit head age }\end{array}$} \\
\hline Gr ivi umil reau age & 0.062 & 0.056 & 0.071 & 0.066 \\
\hline $25-34$ & 0.236 & 0.280 & 0.333 & 0.326 \\
\hline $35-44$ & 0.399 & 0.412 & 0.353 & 0.361 \\
\hline $45-54$ & 0.207 & 0.189 & 0.160 & 0.150 \\
\hline $55+$ & 0.095 & 0.063 & 0.083 & 0.097 \\
\hline \multicolumn{5}{|l|}{ SPM unit head marital status (\%) } \\
\hline 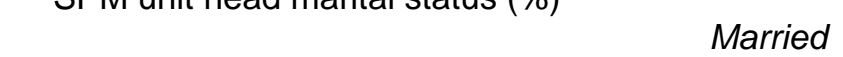 & 0.705 & 0.696 & 0.655 & 0.589 \\
\hline Separated, divorced, or widowed & 0.114 & 0.097 & 0.149 & 0.146 \\
\hline Single, never married & 0.107 & 0.112 & 0.121 & 0.145 \\
\hline Cohabitating & 0.074 & 0.094 & 0.074 & 0.120 \\
\hline \multicolumn{5}{|l|}{ SPM unit head education (\%) } \\
\hline No HS diploma & 0.431 & 0.492 & 0.230 & 0.169 \\
\hline HS diploma & 0.353 & 0.379 & 0.471 & 0.527 \\
\hline Associate's degree & 0.044 & 0.048 & 0.098 & 0.112 \\
\hline Bachelor's degree & 0.172 & 0.081 & 0.201 & 0.191 \\
\hline \multicolumn{5}{|l|}{ SPM characteristics } \\
\hline SPM unit size (persons) & $\begin{array}{c}4.735 \\
(1.575)\end{array}$ & $\begin{array}{c}4.987 \\
(1.570)\end{array}$ & $\begin{array}{c}4.670 \\
(1.595)\end{array}$ & $\begin{array}{c}4.684 \\
(1.545)\end{array}$ \\
\hline Low adult work (<0.5 FTE/capita) (\%) & 0.169 & 0.158 & 0.156 & 0.160 \\
\hline \multicolumn{5}{|l|}{$\begin{array}{l}\text { Geographic characteristics } \\
\text { Region (\%) }\end{array}$} \\
\hline Northeast & 0.166 & 0.133 & 0.114 & 0.118 \\
\hline Midwest & 0.086 & 0.097 & 0.113 & 0.111 \\
\hline South & 0.473 & 0.371 & 0.366 & 0.363 \\
\hline West & 0.275 & 0.399 & 0.408 & 0.407 \\
\hline \multicolumn{5}{|c|}{ Immigrant destination and metropolitan status (\%) } \\
\hline Established, metropolitan & 0.680 & 0.707 & 0.686 & 0.623 \\
\hline Established, nonmetropolitan & 0.015 & 0.015 & 0.019 & 0.034 \\
\hline New, metropolitan & 0.219 & 0.200 & 0.205 & 0.230 \\
\hline New, nonmetropolitan & 0.022 & 0.019 & 0.023 & 0.031 \\
\hline Other, metropolitan & 0.045 & 0.039 & 0.041 & 0.055 \\
\hline Other, nonmetropolitan & 0.012 & 0.014 & 0.015 & 0.020 \\
\hline All, not identifiable & 0.007 & 0.006 & 0.011 & 0.008 \\
\hline Share of total sample (weighted) & 0.057 & 0.374 & 0.155 & 0.413 \\
\hline $\mathrm{N}$ (unweighted) & 3,249 & 21,706 & 8,773 & 24,222 \\
\hline
\end{tabular}

Source: 2014-2019 March CPS. Person weights applied. 
Table A2 Linear regression model of poverty (SPM) among Hispanic children, by immigrant generation

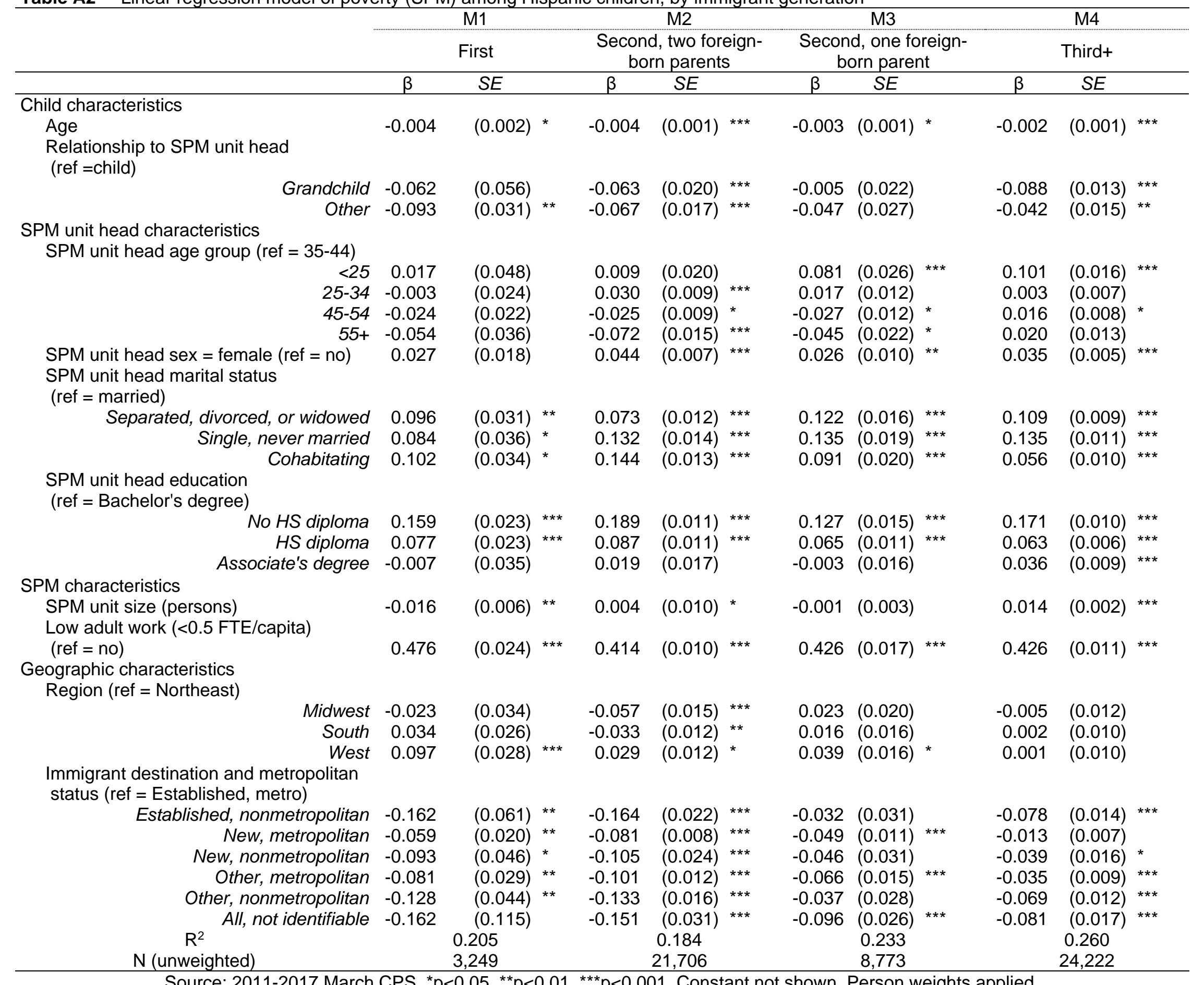

Source: $2011-2017$ March CPS. ${ }^{*} p<0.05,{ }^{* \star} p<0.01,{ }^{* \star *} p<0.001$. Constant not shown. Person weights applied. 
Table A3 Description of sample (White only), by immigrant generation

\begin{tabular}{|c|c|c|c|c|}
\hline & First & $\begin{array}{l}\text { Second, } \\
\text { Two } \\
\text { Foreign- } \\
\text { Born } \\
\text { Parents }\end{array}$ & $\begin{array}{c}\text { Second, } \\
\text { One } \\
\text { Foreign- } \\
\text { Born } \\
\text { Parent }\end{array}$ & Third+ \\
\hline \multicolumn{5}{|l|}{ Poverty } \\
\hline SPM poverty status (\%) & 0.269 & 0.172 & 0.085 & 0.089 \\
\hline \multicolumn{5}{|l|}{ Child characteristics } \\
\hline Age & $\begin{array}{l}10.366 \\
(4.255)\end{array}$ & $\begin{array}{l}8.362 \\
(4.531)\end{array}$ & $\begin{array}{c}8.578 \\
(4.962)\end{array}$ & $\begin{array}{c}8.814 \\
(5.250)\end{array}$ \\
\hline \multicolumn{5}{|l|}{ Relationship to SPM unit head (\%) } \\
\hline Child & 0.947 & 0.947 & 0.957 & 0.917 \\
\hline Grandchild & 0.011 & 0.019 & 0.022 & 0.053 \\
\hline Other & 0.042 & 0.034 & 0.021 & 0.029 \\
\hline \multicolumn{5}{|l|}{$\begin{array}{l}\text { SPM unit head characteristics } \\
\text { SPM unit head age }\end{array}$} \\
\hline 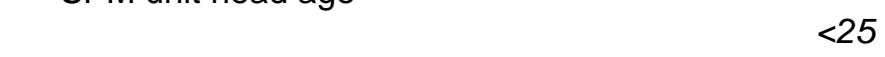 & 0.026 & 0.025 & 0.016 & 0.023 \\
\hline $25-34$ & 0.141 & 0.181 & 0.177 & 0.240 \\
\hline $35-44$ & 0.432 & 0.438 & 0.407 & 0.411 \\
\hline $45-54$ & 0.275 & 0.265 & 0.306 & 0.239 \\
\hline $55+$ & 0.125 & 0.091 & 0.094 & 0.086 \\
\hline \multicolumn{5}{|l|}{ SPM unit head marital status (\%) } \\
\hline Married & 0.882 & 0.856 & 0.797 & 0.769 \\
\hline Separated, divorced, or widowed & 0.056 & 0.079 & 0.126 & 0.124 \\
\hline Single, never married & 0.046 & 0.036 & 0.034 & 0.037 \\
\hline Cohabitating & 0.015 & 0.029 & 0.043 & 0.070 \\
\hline \multicolumn{5}{|l|}{ SPM unit head education (\%) } \\
\hline No HS diploma & 0.078 & 0.112 & 0.024 & 0.052 \\
\hline HS diploma & 0.270 & 0.366 & 0.309 & 0.402 \\
\hline Associate's degree & 0.064 & 0.070 & 0.114 & 0.124 \\
\hline Bachelor's degree & 0.587 & 0.453 & 0.553 & 0.423 \\
\hline \multicolumn{5}{|l|}{ SPM characteristics } \\
\hline SPM unit size (persons) & $\begin{array}{c}4.570 \\
(1.294)\end{array}$ & $\begin{array}{c}4.600 \\
(1.250)\end{array}$ & $\begin{array}{c}4.265 \\
(1.370)\end{array}$ & $\begin{array}{c}4.395 \\
(1.364)\end{array}$ \\
\hline Low adult work (<0.5 FTE/capita) (\%) & 0.231 & 0.115 & 0.088 & 0.093 \\
\hline \multicolumn{5}{|l|}{$\begin{array}{l}\text { Geographic characteristics } \\
\text { Region }(\%)\end{array}$} \\
\hline Northeast & 0.256 & 0.307 & 0.273 & 0.172 \\
\hline Midwest & 0.168 & 0.166 & 0.158 & 0.290 \\
\hline South & 0.287 & 0.264 & 0.316 & 0.356 \\
\hline West & 0.290 & 0.264 & 0.253 & 0.181 \\
\hline \multicolumn{5}{|l|}{ Immigrant destination and metropolitan status (\%) } \\
\hline Established, metropolitan & 0.656 & 0.710 & 0.598 & 0.330 \\
\hline Established, nonmetropolitan & 0.006 & 0.006 & 0.015 & 0.033 \\
\hline New, metropolitan & 0.258 & 0.220 & 0.275 & 0.358 \\
\hline New, nonmetropolitan & 0.020 & 0.015 & 0.029 & 0.096 \\
\hline Other, metropolitan & 0.046 & 0.043 & 0.057 & 0.108 \\
\hline Other, nonmetropolitan & 0.012 & 0.004 & 0.020 & 0.067 \\
\hline All, not identifiable & 0.001 & 0.001 & 0.006 & 0.010 \\
\hline Share of total sample (weighted) & 0.013 & 0.032 & 0.036 & 0.919 \\
\hline $\mathrm{N}$ (unweighted) & 1,402 & 3,350 & 4,358 & 124,255 \\
\hline
\end{tabular}

Source: 2014-2019 March CPS. Person weights applied. 
Table A4 Linear regression model of poverty (SPM) among White children, by immigrant generation

\begin{tabular}{|c|c|c|c|c|c|c|c|c|c|c|c|c|}
\hline & \multicolumn{3}{|c|}{ M1 } & \multicolumn{3}{|c|}{ M2 } & \multicolumn{3}{|c|}{ M3 } & \multicolumn{3}{|c|}{ M4 } \\
\hline & \multicolumn{3}{|c|}{ First } & \multicolumn{3}{|c|}{$\begin{array}{l}\text { Second, two } \\
\text { foreign-born parents }\end{array}$} & \multicolumn{3}{|c|}{$\begin{array}{l}\text { Second, one } \\
\text { foreign-born parent }\end{array}$} & \multicolumn{3}{|c|}{ Third+ } \\
\hline & $\beta$ & $S E$ & & $\beta$ & $S E$ & & $\beta$ & $S E$ & & $\beta$ & $S E$ & \\
\hline \multicolumn{13}{|l|}{ Child characteristics } \\
\hline $\begin{array}{l}\text { Age } \\
\text { Relationship to SPM unit head (ref = child) }\end{array}$ & 0.000 & -0.003 & & -0.006 & -0.002 & $* * *$ & -0.004 & -0.001 & $* \star *$ & -0.002 & $-2 \mathrm{E}-04$ & *** \\
\hline Grandchild & 0.119 & -0.101 & & -0.162 & -0.051 & ** & -0.072 & -0.031 & * & -0.039 & -0.006 & *** \\
\hline Other & 0.056 & -0.079 & & -0.144 & -0.074 & & -0.037 & -0.041 & & -0.036 & -0.007 & *** \\
\hline \multicolumn{13}{|l|}{$\begin{array}{l}\text { SPM unit head characteristics } \\
\text { SPM unit head age group (ref }=35-44)\end{array}$} \\
\hline$<25$ & -0.040 & -0.12 & & -0.003 & -0.084 & & 0.034 & -0.051 & & 0.075 & -0.01 & $* * *$ \\
\hline $25-34$ & 0.105 & -0.042 & * & 0.034 & -0.022 & & 0.027 & -0.013 & * & 0.011 & -0.002 & *** \\
\hline $45-54$ & -0.058 & -0.024 & * & 0.033 & -0.016 & * & 0.038 & -0.011 & $* * *$ & 0.007 & -0.002 & *** \\
\hline $55+$ & -0.008 & -0.04 & & 0.077 & -0.028 & ** & -0.007 & -0.017 & & -0.008 & -0.004 & \\
\hline $\begin{array}{l}\text { SPM unit head sex }=\text { female }(r e f=\text { no }) \\
\text { SPM unit head marital status }(\text { ref }=\text { married })\end{array}$ & -0.014 & -0.023 & & 0.025 & -0.014 & & 0.016 & -0.009 & ** & 0.022 & -0.002 & $* * *$ \\
\hline Separated, divorced, or widowed & 0.130 & -0.049 & $* \star *$ & 0.136 & -0.035 & $* \star *$ & 0.061 & -0.019 & ** & 0.082 & -0.004 & $* * *$ \\
\hline Single, never married & 0.075 & -0.07 & & 0.301 & -0.071 & $* * *$ & 0.240 & -0.041 & $* * *$ & 0.135 & -0.008 & $* * *$ \\
\hline $\begin{array}{c}\text { Cohabitating } \\
\text { SPM unit head education }(r e f=\text { Bachelor's degree })\end{array}$ & -0.143 & -0.063 & & 0.166 & -0.06 & ** & -0.027 & -0.018 & & 0.029 & -0.004 & $* * *$ \\
\hline No HS diploma & 0.310 & -0.053 & $* * *$ & 0.149 & -0.028 & $* * *$ & 0.050 & -0.033 & & 0.134 & -0.006 & $* * *$ \\
\hline HS diploma & 0.201 & -0.029 & $* * *$ & 0.086 & -0.016 & $* * *$ & 0.033 & -0.011 & $* * *$ & 0.039 & -0.002 & $* * *$ \\
\hline Associate's degree & -0.052 & -0.037 & & -0.037 & -0.02 & & -0.010 & -0.013 & & 0.019 & -0.003 & $* * *$ \\
\hline \multicolumn{13}{|l|}{ SPM characteristics } \\
\hline SPM unit size (persons) & 0.005 & -0.01 & & 0.027 & -0.006 & $* * *$ & 0.011 & -0.004 & * & 0.005 & $-8 \mathrm{E}-04$ & $* * *$ \\
\hline Low adult work $(<0.5 \mathrm{FTE} /$ capita $)($ ref $=$ no $)$ & 0.505 & -0.031 & $* * *$ & 0.395 & -0.03 & $* * *$ & 0.399 & -0.029 & $* * *$ & 0.381 & -0.006 & *** \\
\hline \multicolumn{13}{|l|}{$\begin{array}{l}\text { Geographic characteristics } \\
\text { Region (ref = Northeast) }\end{array}$} \\
\hline Midwest & -0.025 & -0.035 & & -0.009 & -0.021 & & -0.026 & -0.015 & & -0.006 & -0.003 & * \\
\hline South & 0.012 & -0.028 & & -0.009 & -0.018 & & -0.042 & -0.011 & $* * *$ & 0.001 & -0.003 & \\
\hline West & -0.066 & -0.029 & ** & 0.001 & -0.019 & & -0.008 & -0.012 & & 0.001 & -0.003 & \\
\hline \multicolumn{13}{|l|}{$\begin{array}{l}\text { Immigrant destination and metropolitan status } \\
\text { (ref = Established, metro) }\end{array}$} \\
\hline Established, nonmetropolitan & -0.213 & -0.053 & $\star \star \star *$ & 0.072 & -0.106 & & 0.132 & -0.051 & $* *$ & -0.022 & -0.006 & *** \\
\hline New, metropolitan & -0.064 & -0.027 & * & -0.043 & -0.015 & $* *$ & -0.039 & -0.01 & $* * *$ & -0.008 & -0.002 & $* * *$ \\
\hline New, nonmetropolitan & -0.049 & -0.082 & & 0.031 & -0.05 & & 0.080 & -0.04 & * & -0.022 & -0.004 & $* * *$ \\
\hline Other, metropolitan & -0.102 & -0.036 & ** & -0.059 & -0.02 & $* *$ & 0.014 & -0.013 & & -0.016 & -0.003 & $\star *$ \\
\hline Other, nonmetropolitan & -0.143 & -0.04 & $* * *$ & -0.165 & -0.05 & $* \star *$ & 0.021 & -0.027 & & -0.012 & -0.003 & $* * *$ \\
\hline All, not identifiable & -0.316 & -0.058 & $* * *$ & 0.152 & -0.15 & & -0.006 & -0.049 & & -0.029 & -0.008 & $* * *$ \\
\hline $\begin{array}{c}R^{2} \\
N \text { (unweighted) }\end{array}$ & & $\begin{array}{l}0.366 \\
1,402\end{array}$ & & & .215 & & & .254 & & & $\begin{array}{l}.230 \\
4,255\end{array}$ & \\
\hline
\end{tabular}

Source: $2011-2017$ March CPS. ${ }^{\star} p<0.05,{ }^{* \star} p<0.01,{ }^{\star \star *} p<0.001$. Constant not shown. Person weights applied. 
Table A5 Description of sample (Asian only), by immigrant generation

\begin{tabular}{|c|c|c|c|c|}
\hline & First & $\begin{array}{c}\text { Second, Two } \\
\text { Foreign-Born } \\
\text { Parents }\end{array}$ & $\begin{array}{c}\text { Second, One } \\
\text { Foreign-Born } \\
\text { Parent }\end{array}$ & Third+ \\
\hline \multicolumn{5}{|l|}{ Poverty } \\
\hline SPM poverty status (\%) & 0.194 & 0.143 & 0.087 & 0.117 \\
\hline \multicolumn{5}{|l|}{ Child characteristics } \\
\hline Ri. & $\begin{array}{l}10.245 \\
(4.702)\end{array}$ & $\begin{array}{l}8.109 \\
(4.974)\end{array}$ & $\begin{array}{l}7.475 \\
(5.010)\end{array}$ & $\begin{array}{l}8.565 \\
(5.882)\end{array}$ \\
\hline \multicolumn{5}{|l|}{ Relationship to SPM unit head (\%) } \\
\hline Child & 0.898 & 0.927 & 0.880 & 0.882 \\
\hline Grandchild & 0.025 & 0.031 & 0.092 & 0.077 \\
\hline Other & 0.078 & 0.042 & 0.028 & 0.041 \\
\hline \multicolumn{5}{|l|}{$\begin{array}{l}\text { SPM unit head characteristics } \\
\text { SPM unit head age }\end{array}$} \\
\hline 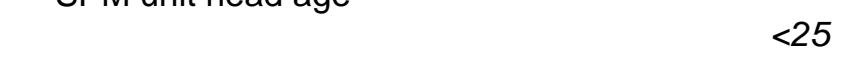 & 0.027 & 0.021 & 0.024 & 0.028 \\
\hline $25-34$ & 0.156 & 0.166 & 0.220 & 0.200 \\
\hline $35-44$ & 0.431 & 0.445 & 0.437 & 0.414 \\
\hline $45-54$ & 0.280 & 0.281 & 0.193 & 0.211 \\
\hline $55+$ & 0.105 & 0.087 & 0.126 & 0.147 \\
\hline \multicolumn{5}{|l|}{$\begin{array}{l}\text { SPM unit head sex }=\text { female }(\%) \\
\text { SPM unit head marital status }(\%)\end{array}$} \\
\hline 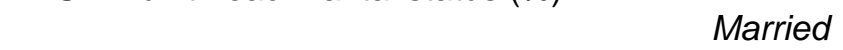 & 0.885 & 0.882 & 0.827 & 0.794 \\
\hline Separated, divorced, or widowed & 0.049 & 0.054 & 0.098 & 0.071 \\
\hline Single, never married & 0.046 & 0.041 & 0.034 & 0.046 \\
\hline Cohabitating & 0.020 & 0.024 & 0.041 & 0.089 \\
\hline \multicolumn{5}{|l|}{ SPM unit head education (\%) } \\
\hline No HS diploma & 0.122 & 0.081 & 0.043 & 0.056 \\
\hline HS diploma & 0.220 & 0.272 & 0.211 & 0.389 \\
\hline Associate's degree & 0.046 & 0.070 & 0.129 & 0.075 \\
\hline Bachelor's degree & 0.612 & 0.578 & 0.617 & 0.480 \\
\hline \multicolumn{5}{|l|}{ SPM characteristics } \\
\hline SPM unit size (persons) & $\begin{array}{c}4.454 \\
(1.573)\end{array}$ & $\begin{array}{c}4.575 \\
(1.421)\end{array}$ & $\begin{array}{c}4.708 \\
(1.963)\end{array}$ & $\begin{array}{c}4.818 \\
(1.889)\end{array}$ \\
\hline Low adult work (<0.5 FTE/capita) (\%) & 0.155 & 0.096 & 0.092 & 0.116 \\
\hline \multicolumn{5}{|l|}{$\begin{array}{l}\text { Geographic characteristics } \\
\text { Region (\%) }\end{array}$} \\
\hline Northeast & 0.219 & 0.246 & 0.119 & 0.119 \\
\hline Midwest & 0.178 & 0.118 & 0.123 & 0.134 \\
\hline South & 0.302 & 0.254 & 0.181 & 0.248 \\
\hline West & 0.301 & 0.381 & 0.576 & 0.499 \\
\hline \multicolumn{5}{|c|}{ Immigrant destination and metropolitan status (\%) } \\
\hline Established, metropolitan & 0.602 & 0.734 & 0.716 & 0.562 \\
\hline Established, nonmetropolitan & 0.007 & 0.005 & no obs & 0.012 \\
\hline New, metropolitan & 0.301 & 0.213 & 0.235 & 0.295 \\
\hline New, nonmetropolitan & 0.013 & 0.010 & 0.013 & 0.053 \\
\hline Other, metropolitan & 0.059 & 0.031 & 0.030 & 0.061 \\
\hline Other, nonmetropolitan & 0.013 & 0.005 & 0.005 & 0.014 \\
\hline All, not identifiable & 0.005 & 0.002 & no obs & 0.002 \\
\hline Share of total sample (weighted) & 0.180 & 0.586 & 0.081 & 0.153 \\
\hline $\mathrm{N}$ (unweighted) & 2,170 & 6,521 & 1,008 & 2,432 \\
\hline
\end{tabular}

Source: 2014-2019 March CPS. Person weights applied. 
Table A6 Linear regression model of poverty (SPM) among Asian children, by immigrant generation

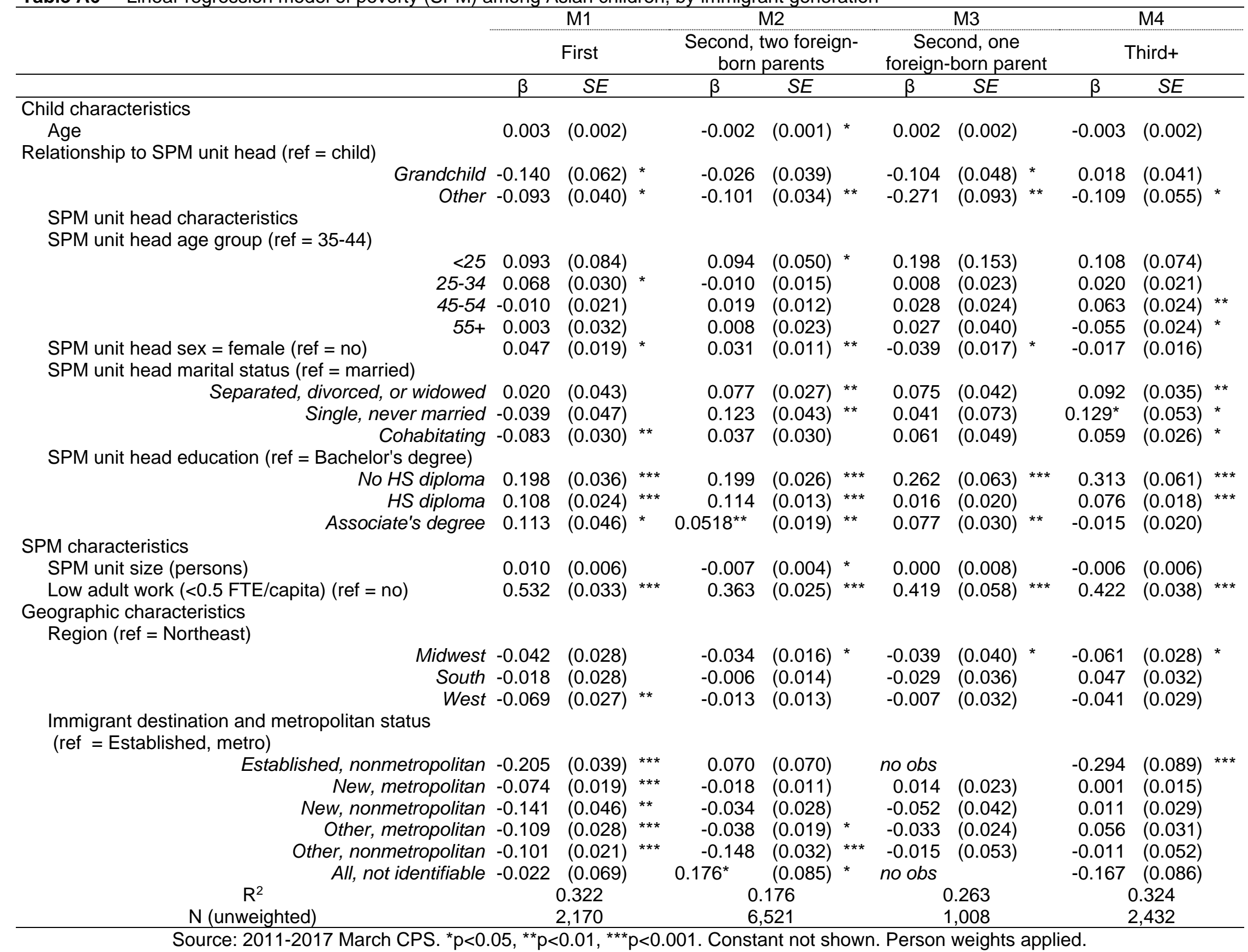


Table A7 Description of sample (Black only), by immigrant generation

\begin{tabular}{|c|c|c|c|c|}
\hline & First & $\begin{array}{c}\text { Second, Two } \\
\text { Foreign-Born } \\
\text { Parents }\end{array}$ & $\begin{array}{c}\text { Second, One } \\
\text { Foreign-Born } \\
\text { Parent }\end{array}$ & Third+ \\
\hline \multicolumn{5}{|l|}{ Poverty } \\
\hline SPM poverty status (\%) & 0.325 & 0.213 & 0.163 & 0.258 \\
\hline \multicolumn{5}{|l|}{ Child characteristics } \\
\hline Age & $\begin{array}{l}11.160 \\
(4.863)\end{array}$ & $\begin{array}{l}7.704 \\
(4.933)\end{array}$ & $\begin{array}{l}8.234 \\
(4.781)\end{array}$ & $\begin{array}{l}8.625 \\
(5.207)\end{array}$ \\
\hline \multicolumn{5}{|l|}{ Relationship to SPM unit head (\%) } \\
\hline Child & 0.879 & 0.914 & 0.904 & 0.826 \\
\hline Grandchild & 0.027 & 0.028 & 0.072 & 0.114 \\
\hline Other & 0.095 & 0.058 & 0.023 & 0.060 \\
\hline \multicolumn{5}{|l|}{$\begin{array}{l}\text { SPM unit head characteristics } \\
\text { SPM unit head age }\end{array}$} \\
\hline 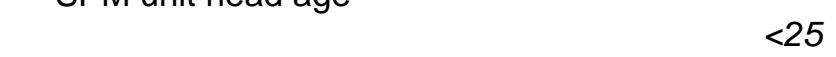 & 0.049 & 0.044 & 0.052 & 0.060 \\
\hline $25-34$ & 0.147 & 0.183 & 0.228 & 0.323 \\
\hline $35-44$ & 0.399 & 0.396 & 0.414 & 0.334 \\
\hline $45-54$ & 0.293 & 0.273 & 0.166 & 0.163 \\
\hline $55+$ & 0.112 & 0.103 & 0.140 & 0.121 \\
\hline SPM unit head sex $=$ female $(\%)$ & 0.534 & 0.435 & 0.358 & 0.268 \\
\hline SPM unit head marital status (\%) & 0.47 & 0.56 & 0.64 & 0.73 \\
\hline Married & 0.682 & 0.669 & 0.511 & 0.357 \\
\hline Separated, divorced, or widowed & 0.119 & 0.164 & 0.202 & 0.185 \\
\hline Single, never married & 0.174 & 0.115 & 0.227 & 0.372 \\
\hline Cohabitating & 0.053 & 0.052 & 0.060 & 0.086 \\
\hline \multicolumn{5}{|l|}{ SPM unit head education (\%) } \\
\hline No HS diploma & 0.171 & 0.142 & 0.099 & 0.108 \\
\hline HS diploma & 0.376 & 0.371 & 0.405 & 0.577 \\
\hline Associate's degree & 0.088 & 0.098 & 0.107 & 0.124 \\
\hline Bachelor's degree & 0.365 & 0.389 & 0.388 & 0.192 \\
\hline \multicolumn{5}{|l|}{ SPM characteristics } \\
\hline SPM unit size (persons) & $\begin{array}{c}4.948 \\
(1.782)\end{array}$ & $\begin{array}{c}4.866 \\
(1.657)\end{array}$ & $\begin{array}{c}4.264 \\
(1.433)\end{array}$ & $\begin{array}{c}4.247 \\
(1.522)\end{array}$ \\
\hline Low adult work (<0.5 FTE/capita) (\%) & 0.232 & 0.159 & 0.149 & 0.242 \\
\hline \multicolumn{5}{|l|}{$\begin{array}{l}\text { Geographic characteristics } \\
\text { Region (\%) }\end{array}$} \\
\hline Northeast & 0.251 & 0.302 & 0.331 & 0.112 \\
\hline Midwest & 0.168 & 0.136 & 0.106 & 0.197 \\
\hline South & 0.468 & 0.474 & 0.454 & 0.616 \\
\hline West & 0.114 & 0.088 & 0.109 & 0.075 \\
\hline \multicolumn{5}{|l|}{ Immigrant destination and metropolitan status (\%) } \\
\hline Established, metropolitan & 0.564 & 0.700 & 0.660 & 0.384 \\
\hline Established, nonmetropolitan & 0.023 & 0.004 & 0.005 & 0.017 \\
\hline New, metropolitan & 0.318 & 0.250 & 0.270 & 0.385 \\
\hline New, nonmetropolitan & 0.008 & 0.006 & 0.016 & 0.042 \\
\hline Other, metropolitan & 0.074 & 0.035 & 0.040 & 0.116 \\
\hline Other, nonmetropolitan & 0.007 & 0.002 & 0.009 & 0.053 \\
\hline All, not identifiable & 0.007 & 0.002 & 0.001 & 0.003 \\
\hline Share of total sample (weighted) & 0.032 & 0.100 & 0.038 & 0.830 \\
\hline $\mathrm{N}$ (unweighted) & 873 & 2,287 & 859 & 21,514 \\
\hline
\end{tabular}

Source: 2014-2019 March CPS. Person weights applied. 
Table A8 Linear regression model of poverty (SPM) among Black children, by immigrant generation

\begin{tabular}{|c|c|c|c|c|c|c|c|c|c|c|c|c|}
\hline & \multicolumn{3}{|c|}{ M1 } & \multicolumn{3}{|c|}{ M2 } & \multicolumn{3}{|c|}{ M3 } & \multicolumn{3}{|c|}{ M4 } \\
\hline & \multicolumn{3}{|c|}{ First } & \multicolumn{3}{|c|}{$\begin{array}{l}\text { Second, two } \\
\text { foreign-born } \\
\text { parents }\end{array}$} & \multicolumn{3}{|c|}{$\begin{array}{l}\text { Second, one } \\
\text { foreign-born parent }\end{array}$} & \multicolumn{3}{|c|}{ Third+ } \\
\hline & $\beta$ & $S E$ & & $\beta$ & $S E$ & & $\beta$ & SE & & $\beta$ & SE & \\
\hline \multicolumn{13}{|l|}{ Child characteristics } \\
\hline $\begin{array}{l}\text { Age } \\
\text { Relationship to SPM unit head (ref = child) }\end{array}$ & -0.013 & $(0.004)$ & $\star \star \star *$ & -0.007 & $(0.002)$ & $* * *$ & -0.008 & $(0.003)$ & ** & -0.004 & $(0.001)$ & $\star \star *$ \\
\hline $\begin{array}{r}\text { Grandchild } \\
\text { Other }\end{array}$ & $\begin{array}{l}-0.047 \\
-0.147\end{array}$ & $\begin{array}{l}(0.109) \\
(0.065)\end{array}$ & & $\begin{array}{l}-0.082 \\
-0.059\end{array}$ & $\begin{array}{l}(0.061) \\
(0.047)\end{array}$ & & $\begin{array}{l}-0.091 \\
-0.210\end{array}$ & $\begin{array}{l}(0.062) \\
(0.064)\end{array}$ & ** & $\begin{array}{l}-0.013 \\
-0.061\end{array}$ & $\begin{array}{l}(0.013) \\
(0.015)\end{array}$ & $* * *$ \\
\hline \multicolumn{13}{|l|}{$\begin{array}{l}\text { SPM unit head characteristics } \\
\text { SPM unit head age group (ref }=35-44)\end{array}$} \\
\hline $\begin{array}{l}\text { SPM unit head sex }=\text { female }(\text { ref }=\text { no }) \\
\text { SPM unit head marital status }(\text { ref }=\text { married })\end{array}$ & $\begin{array}{r}-0.051 \\
-0.085 \\
-0.068 \\
-0.019 \\
0.057\end{array}$ & $\begin{array}{l}(0.076) \\
(0.057) \\
(0.039) \\
(0.061) \\
(0.041)\end{array}$ & & $\begin{array}{r}0.158 \\
-0.034 \\
0.004 \\
0.051 \\
0.047\end{array}$ & $\begin{array}{l}(0.062) \\
(0.026) \\
(0.021) \\
(0.036) \\
(0.019)\end{array}$ & * & $\begin{array}{r}0.022 \\
-0.101 \\
0.030 \\
-0.049 \\
0.007\end{array}$ & $\begin{array}{l}(0.101) \\
(0.035) \\
(0.032) \\
(0.042) \\
(0.023)\end{array}$ & ** & $\begin{array}{r}0.147 \\
-0.003 \\
-0.002 \\
0.019 \\
0.018\end{array}$ & $\begin{array}{l}(0.019) \\
(0.008) \\
(0.008) \\
(0.013) \\
(0.007)\end{array}$ & $\star \star *$ \\
\hline Separated, divorced, or widowed & -0.061 & $(0.051)$ & & 0.001 & $(0.028)$ & & 0.180 & $(0.039)$ & $* * *$ & 0.112 & $(0.010)$ & $* * *$ \\
\hline Single, never married & 0.059 & $(0.054)$ & & 0.064 & $(0.033)$ & & 0.216 & $(0.044)$ & *** & 0.146 & (0.009) & $\star * *$ \\
\hline SPM unit head education (ref = Bachelor's degree) & -0.039 & $(0.075)$ & & -0.074 & $(0.029)$ & $\star * *$ & 0.128 & $(0.061)$ & * & 0.075 & $(0.012)$ & $\star \star *$ \\
\hline No HS diploma & -0.019 & $(0.045)$ & & 0.255 & $(0.031)$ & $\star \star \star$ & 0.113 & $(0.066)$ & & 0.140 & $(0.013)$ & $\star \star \star *$ \\
\hline HS diploma & 0.212 & $(0.044)$ & *** & 0.177 & $(0.022)$ & $\star \star *$ & 0.065 & $(0.024)$ & ** & 0.076 & $(0.007)$ & $\star \star * *$ \\
\hline Associate's degree & -0.003 & $(0.063)$ & & 0.106 & $(0.027)$ & $* * *$ & 0.025 & $(0.042)$ & & 0.030 & $(0.009)$ & $* *$ \\
\hline \multicolumn{13}{|l|}{ SPM characteristics } \\
\hline SPM unit size (persons) & -0.005 & $(0.010)$ & & 0.004 & $(0.006)$ & & 0.019 & $(0$. & & 0.012 & $(0.002)$ & *** \\
\hline Low adult work (<0.5 FTE/capita) $($ ref $=$ no) & 0.466 & $(0.043)$ & $\star \star * *$ & 0.428 & $(0.031)$ & $\star * \star$ & 0.397 & $(0.052)$ & $* \star *$ & 0.444 & $(0.009)$ & $* \star *$ \\
\hline \multicolumn{13}{|l|}{$\begin{array}{l}\text { Geographic characteristics } \\
\text { Region (ref = Northeast) }\end{array}$} \\
\hline Midwest & -0.075 & $(0.054)$ & & -0.048 & $(0.032)$ & * & 0.010 & $(0.046)$ & & 0.016 & $(0.013)$ & \\
\hline South & 0.052 & $(0.045)$ & & 0.074 & $(0.021)$ & $\star * *$ & 0.032 & $(0.030)$ & & 0.030 & $(0.011)$ & ** \\
\hline West & -0.083 & $(0.057)$ & & 0.027 & $(0.035)$ & & -0.008 & $(0.038)$ & & 0.039 & $(0.015)$ & * \\
\hline \multicolumn{13}{|l|}{$\begin{array}{l}\text { Immigrant destination and metropolitan status } \\
\text { (ref = Established, metro) }\end{array}$} \\
\hline Established, nonmetropolitan & -0.243 & $(0.065)$ & $* \star *$ & -0.102 & $(0.067)$ & & -0.285 & $(0.054)$ & $* * *$ & 0.024 & $(0.026)$ & \\
\hline New, metropolitan & 0.070 & $(0.041)$ & & 0.040 & $(0.022)$ & & -0.046 & $(0.028)$ & & -0.003 & $(0.008)$ & \\
\hline New, nonmetropolitan & -0.034 & $(0.210)$ & & 0.036 & $(0.211)$ & & -0.247 & $(0.086)$ & ** & -0.014 & $(0.017)$ & \\
\hline Other, metropolitan & -0.046 & $(0.042)$ & & -0.072 & $(0.027)$ & ** & 0.046 & $(0.052)$ & & -0.015 & $(0.009)$ & \\
\hline Other, nonmetropolitan & -0.031 & $(0.067)$ & & 0.016 & $(0.076)$ & & 0.034 & $(0.090)$ & & -0.061 & $(0.012)$ & $\star \star \star *$ \\
\hline All, not identifiable & -0.262 & $(0.051)$ & $* \star *$ & -0.216 & $(0.079)$ & $* *$ & -0.409 & $(0.093)$ & $* * *$ & -0.057 & $(0.037)$ & \\
\hline $\begin{array}{c}\mathrm{R}^{2} \\
\mathrm{~N} \text { (unweighted) }\end{array}$ & & $\begin{array}{l}0.304 \\
873\end{array}$ & & & $\begin{array}{l}0.278 \\
2,287\end{array}$ & & & $\begin{array}{l}0.309 \\
859\end{array}$ & & & 0.287 & \\
\hline
\end{tabular}

Source: $2011-2017$ March CPS. ${ }^{\star} p<0.05,{ }^{* *} p<0.01,{ }^{* \star *} p<0.001$. Constant not shown. Person weights applied. 
Table A9 Counterfactual predictions of poverty (SPM) using third+ gen risk distribution among White children, immigrant generation

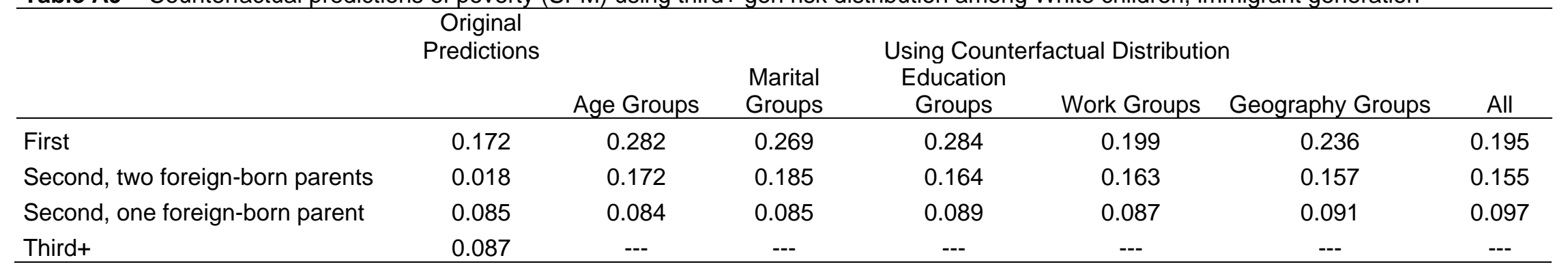

Table A10 Counterfactual predictions of poverty (SPM) using Asian third+ gen risk distribution among Asian children, by immigrant generation

\begin{tabular}{|c|c|c|c|c|c|c|c|}
\hline ras & \multirow[t]{2}{*}{$\begin{array}{c}\text { Original } \\
\text { Predictions }\end{array}$} & \multicolumn{6}{|c|}{ Using Counterfactual Distribution } \\
\hline & & Age Groups & $\begin{array}{l}\text { Marital } \\
\text { Groups }\end{array}$ & $\begin{array}{c}\text { Education } \\
\text { Groups }\end{array}$ & Work Groups & Geography Groups & All \\
\hline First & 0.194 & 0.198 & 0.189 & 0.203 & 0.176 & --- & 0.183 \\
\hline Second, two foreign-born parents & 0.143 & 0.143 & 0.148 & 0.152 & 0.151 & --- & 0.163 \\
\hline Second, one foreign-born parent & 0.087 & 0.089 & 0.089 & 0.089 & 0.097 & --- & 0.102 \\
\hline Third+ & 0.117 & --- & --- & --- & --- & --- & --- \\
\hline
\end{tabular}

Table A11 Counterfactual predictions of poverty (SPM) using Black third+ gen risk distribution among Black children, by immigrant generation

\begin{tabular}{|c|c|c|c|c|c|c|c|}
\hline & $\begin{array}{c}\text { Original } \\
\text { Predictions }\end{array}$ & & & Using Cou & actual Dis & tion & \\
\hline & & & Marital & Education & Work & & \\
\hline & & Age Groups & Groups & Groups & Groups & Geography Groups & All \\
\hline First & 0.325 & 0.318 & 0.330 & 0.368 & 0.329 & 0.327 & 0.374 \\
\hline Second, two foreign-born parents & 0.213 & 0.211 & 0.227 & 0.243 & 0.248 & 0.213 & 0.291 \\
\hline Second, one foreign-born parent & 0.163 & 0.155 & 0.195 & 0.176 & 0.200 & 0.152 & 0.225 \\
\hline Third+ & 0.258 & --- & --- & -- & --- & --- & --- \\
\hline
\end{tabular}


Table A12 Linear regression model of poverty (SPM) among Hispanic children, by immigrant generation (5 groups)

\begin{tabular}{|c|c|c|c|c|c|c|c|c|c|c|c|c|c|c|c|}
\hline & \multicolumn{3}{|c|}{ M1 } & \multicolumn{3}{|c|}{ M2 } & \multirow{2}{*}{\multicolumn{3}{|c|}{$\begin{array}{c}\text { M3 } \\
\text { Second, two } \\
\text { foreign-born } \\
\text { parents }\end{array}$}} & \multirow{2}{*}{\multicolumn{3}{|c|}{$\begin{array}{c}\text { M4 } \\
\text { Second, one } \\
\text { foreign-born } \\
\text { parent }\end{array}$}} & \multicolumn{3}{|c|}{ M5 } \\
\hline & \multicolumn{3}{|c|}{$\begin{array}{l}\text { First, not U.S. } \\
\text { citizen }\end{array}$} & \multicolumn{3}{|c|}{ First, U.S. citizen } & & & & & & & \multicolumn{3}{|c|}{ Third+ } \\
\hline & $\beta$ & $S E$ & & $\beta$ & $S E$ & & $\beta$ & $S E$ & & $\beta$ & SE & & $\beta$ & $S E$ & \\
\hline $\begin{array}{l}\text { Age } \\
\text { Relationship to SPM unit head (ref = child) }\end{array}$ & -0.005 & $(0.002)$ & * & -0.004 & $(0.004)$ & & -0.004 & $(0.001)$ & $* * *$ & -0.003 & $(0.001)$ & * & -0.002 & $(0.001)$ & $* * *$ \\
\hline $\begin{array}{r}\text { Grandchild } \\
\text { Other }\end{array}$ & $\begin{array}{l}-0.069 \\
-0.121\end{array}$ & $\begin{array}{l}(0.061) \\
(0.033)\end{array}$ & $* \star *$ & $\begin{array}{l}-0.211 \\
-0.046\end{array}$ & $\begin{array}{l}(0.116) \\
(0.090)\end{array}$ & $* * *$ & $\begin{array}{l}-0.063 \\
-0.067\end{array}$ & $\begin{array}{l}(0.020) \\
(0.017)\end{array}$ & $* * *$ & $\begin{array}{l}-0.005 \\
-0.047\end{array}$ & $\begin{array}{l}(0.022) \\
(0.027)\end{array}$ & & $\begin{array}{l}-0.088 \\
-0.042\end{array}$ & $\begin{array}{l}(0.013) \\
(0.015)\end{array}$ & $\stackrel{* * *}{* *}$ \\
\hline \multicolumn{16}{|l|}{$\begin{array}{l}\text { SPM unit head characteristics } \\
\text { SPM unit head age group }(\text { ref }=35-44)\end{array}$} \\
\hline $\begin{array}{r}<25 \\
25-34 \\
45-54 \\
55+\end{array}$ & $\begin{array}{r}0.063 \\
0.008 \\
-0.028 \\
0.019\end{array}$ & $\begin{array}{l}(0.052) \\
(0.025) \\
(0.026) \\
(0.042)\end{array}$ & & $\begin{array}{r}-0.198 \\
-0.165 \\
-0.010 \\
0.140\end{array}$ & $\begin{array}{l}(0.089) \\
(0.064) \\
(0.042) \\
(0.058)\end{array}$ & * & $\begin{array}{r}0.009 \\
0.030 \\
-0.025 \\
-0.072\end{array}$ & $\begin{array}{l}(0.020) \\
(0.009) \\
(0.009) \\
(0.015)\end{array}$ & $\begin{array}{l}* * * \\
* \\
* * *\end{array}$ & $\begin{array}{r}0.081 \\
0.017 \\
-0.027 \\
-0.045\end{array}$ & $\begin{array}{l}(0.026) \\
(0.012) \\
(0.012) \\
(0.022)\end{array}$ & $\begin{array}{l}* * * \\
* \\
*\end{array}$ & $\begin{array}{l}0.101 \\
0.003 \\
0.016 \\
0.020\end{array}$ & $\begin{array}{l}(0.016) \\
(0.007) \\
(0.008) \\
(0.013)\end{array}$ & $\left\{\begin{array}{l}* * * \\
*\end{array}\right.$ \\
\hline $\begin{array}{l}\text { SPM unit head sex }=\text { female }(r e f=\text { no }) \\
\text { SPM unit head marital status } \\
(\text { ref }=\text { married })\end{array}$ & 0.002 & $(0.020)$ & & 0.140 & $(0.036)$ & $* * *$ & 0.044 & $(0.007)$ & $* * *$ & 0.026 & $(0.010)$ & ** & 0.035 & $(0.005)$ & $* * *$ \\
\hline Separated, divorced, or widowed & 0.115 & $(0.0$ & $* * *$ & 0.027 & $(0.067)$ & & 0.073 & $(0.012)$ & $* * *$ & 0.122 & $(0.0$ & $\star \star *$ & 0.109 & $(0.009)$ & $* * *$ \\
\hline Single, never married & 0.068 & $(0.039)$ & & 0.232 & $(0.084)$ & & 0.132 & $(0.014)$ & $* * *$ & 0.135 & $(0.019)$ & $\star * *$ & 0.135 & $(0.011)$ & )*** \\
\hline Cohabitating & 0.112 & $(0.036)$ & ** & -0.100 & $(0.086)$ & * & 0.144 & $(0.013)$ & $* * *$ & 0.091 & $(0.020)$ & $* * *$ & 0.056 & $(0.010)$ & $* * *$ \\
\hline \multicolumn{16}{|l|}{$\begin{array}{l}\text { SPM unit head education } \\
\text { (ref = Bachelor's degree) }\end{array}$} \\
\hline No HS diploma & 0.173 & $(0.026)$ & $* * *$ & 0.103 & $(0.058)$ & & 0.189 & $(0.011)$ & $* * *$ & 0.127 & $(0.015)$ & $\star \star * *$ & 0.171 & $(0.010)$ & $* * *$ \\
\hline HS diploma & 0.0 & & $\star \star \star *$ & 0.045 & $(0.048)$ & & 0.087 & $(0.011)$ & $\star \star * *$ & 0.065 & $(0.011)$ & 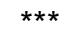 & 0.063 & $(0$. & *** \\
\hline Associate's degree & -0.003 & $(0.046)$ & & -0.036 & $(0.061)$ & & 0.019 & $(0.017)$ & & -0.003 & $(0.016)$ & & 0.036 & $(0.009)$ & )$^{* * *}$ \\
\hline \multicolumn{16}{|l|}{ SPM characteristics } \\
\hline $\begin{array}{l}\text { SPM unit size (persons) } \\
\text { Low adult work }(<05 \mathrm{FTE} /\end{array}$ & 0.020 & $(0.006)$ & $* * *$ & 0.014 & $(0.013)$ & & 0.004 & $(0.010)$ & * & -0.001 & $(0.003)$ & & 0.014 & $(0.002)$ & *** \\
\hline$($ ref $=$ no $)$ & 0.484 & $(0.025)$ & $* * *$ & 0.389 & $(0.066)$ & $\star \star \star *$ & 0.414 & $(0.010)$ & $* * *$ & 0.426 & $(0.017)$ & $* \star *$ & 0.426 & $(0.011)$ & $* * *$ \\
\hline \multicolumn{16}{|l|}{$\begin{array}{l}\text { Geographic characteristics } \\
\text { Region (ref = Northeast) }\end{array}$} \\
\hline Midwest & -0.003 & $(0$. & & -0.094 & $(0 . c$ & & -0.057 & $(0$. & $* * *$ & 0.023 & $(0.020)$ & & -0.005 & $(0$. & \\
\hline South & 0.064 & $(0$. & & 0.111 & $(0.050)$ & ** & -0.033 & $(0.012)$ & ** & 0.016 & $(0.0$ & & 0.002 & & \\
\hline West & 0.130 & $(0.031)$ & $* * *$ & -0.044 & $(0.056)$ & & 0.029 & $(0.012)$ & * & 0.039 & $(0.016)$ & * & 0.001 & $(0.010)$ & \\
\hline \multicolumn{16}{|c|}{$\begin{array}{l}\text { Immigrant destination and metropolitan } \\
\text { status (ref = Established, metro) }\end{array}$} \\
\hline Established, nonmetropolitan & -0.184 & $(0.067)$ & $* * *$ & -0.046 & $(0.122)$ & & -0.164 & $(0.022)$ & $* * *$ & -0.032 & $(0.031)$ & & -0.078 & $(0.014)$ & $* * *$ \\
\hline New, metropolitan & -0.055 & $(0.022)$ & $* * *$ & -0.092 & $(0.047)$ & * & -0.081 & $(0.008)$ & $* * *$ & -0.049 & $(0.011)$ & $\star * *$ & -0.013 & $(0 . c$ & \\
\hline New, nonmetropolitan & -0.077 & $(0.062)$ & & -0.134 & $(0.068)$ & * & -0.105 & $(0.024)$ & $\star * *$ & -0.046 & $(0.031)$ & & -0.039 & $(0.016)$ & * \\
\hline Other, metropolitan & -0.088 & $(0.033)$ & $* * *$ & -0.044 & $(0.052)$ & & -0.101 & $(0.012)$ & $* * *$ & -0.066 & $(0.015)$ & $\star * *$ & -0.035 & ; $(0.009)$ & $* * *$ \\
\hline Other, nonmetropolitan & -0.181 & $(0.050)$ & $* \star *$ & 0.104 & $(0.097)$ & & -0.133 & $(0.016)$ & $\star * *$ & -0.037 & $(0.028)$ & & -0.069 & $(0.012)$ & $* * *$ \\
\hline All, not identifiable & -0.217 & $(0.148)$ & & 0.044 & $(0.237)$ & & -0.151 & $(0.031)$ & $* * *$ & -0.096 & $(0.026)$ & $\star * *$ & -0.081 & $(0.017)$ & $* * *$ \\
\hline $\mathrm{R}^{2}$ & & 0.219 & & & 0.213 & & & 0.184 & & & 0.233 & & & 0.260 & \\
\hline $\mathrm{N}$ (unweighted) & & 2,685 & & & 564 & & & 21,706 & & & 8,773 & & & 24,222 & \\
\hline
\end{tabular}

Source: 2011-2017 March CPS. ${ }^{*} \mathrm{p}<0.05,{ }^{\star *} \mathrm{p}<0.01,{ }^{* *} \mathrm{p}<0.001$. Constant not shown. Person weights applied. 
Table A13 Counterfactual predictions of poverty (SPM) using third+ gen risk distribution among Hispanic children, by immigrant generation (5 groups)

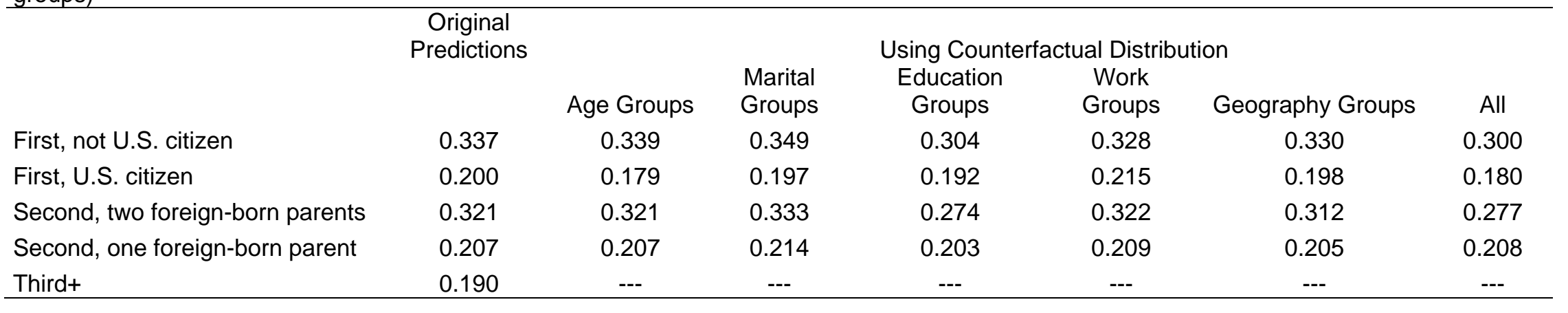




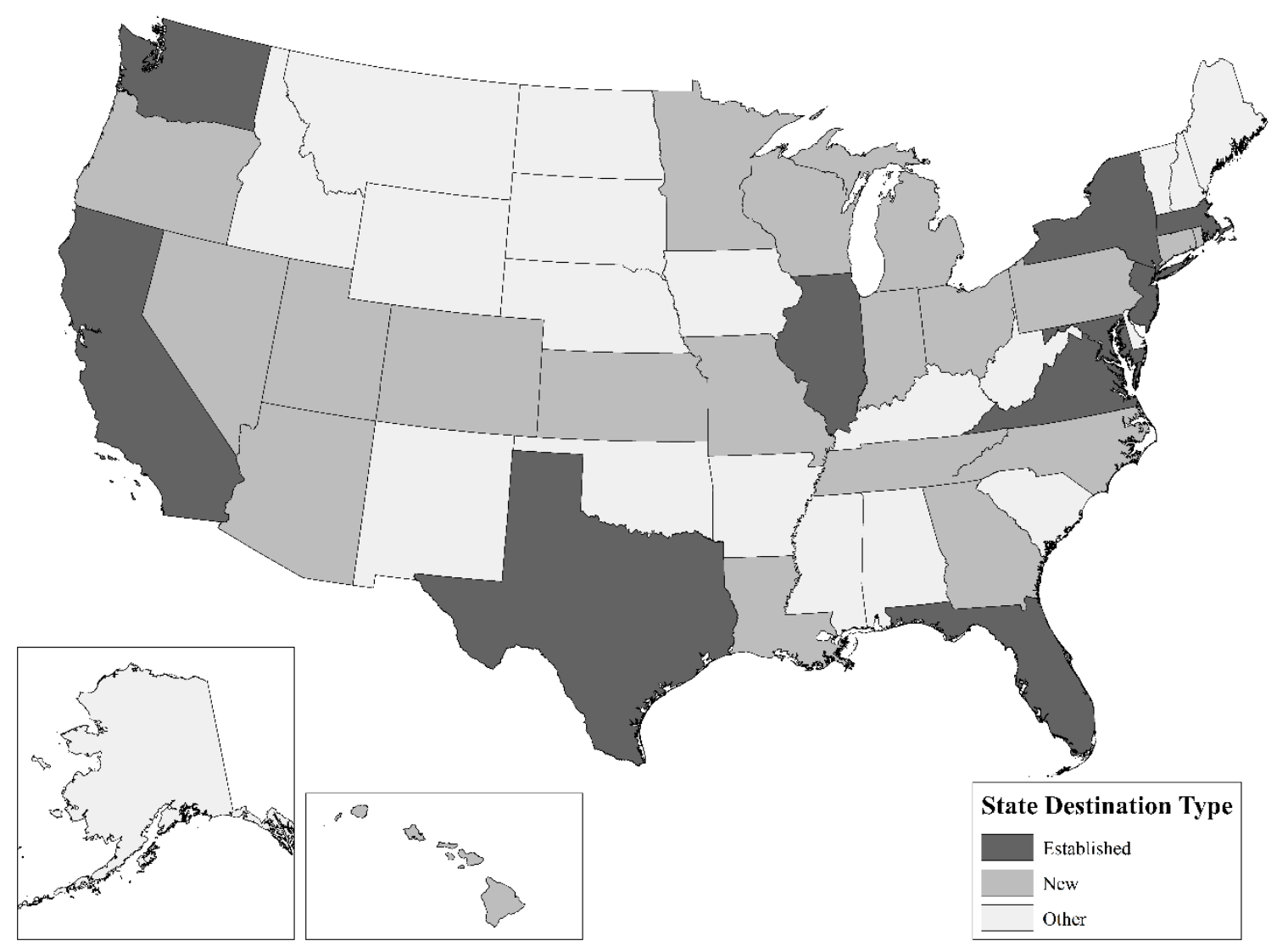

Figure A1. States by destination type. 